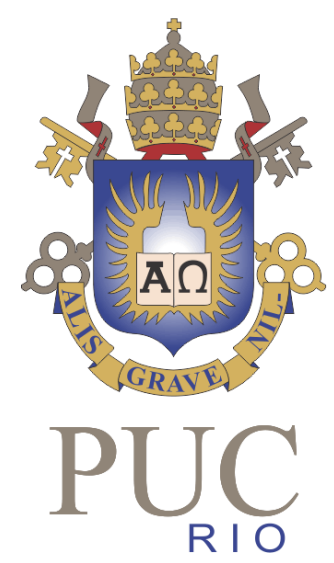

PONTIFÍCIA UNIVERSIDADE CATÓLICA DO RIO DE JANEIRO

Empreender em Favelas?Vantagens e Desvantagens na Perspectiva de Empreendedores da Rocinha

Flávio Abner-Cahn Alvarenga Brazão

TRABALHO DE CONCLUSÃO DE CURSO CENTRO DE CIÊNCIAS SOCIAIS - CCS
DEPARTAMENTO DE ADMINISTRAÇÃO Graduação em Administração de Empresas 
Flávio Abner-Cahn Alvarenga Brazão

\title{
Empreender em Favelas? Vantagens e Desvantagens na Perspectiva de Empreendedores da Rocinha
}

\author{
Trabalho de Conclusão de Curso \\ Trabalho de Conclusão de Curso, apresentado ao programa de \\ graduação em Administração da PUC-Rio como requisito \\ parcial para a obtenção do titulo de graduação em \\ Administração.
}

Orientador: Alessandra de Sá Mello da Costa

Rio de Janeiro, 10 de junho de 2015. 


\section{Agradecimentos}

Primeiramente, gostaria de agradecer aos meus pais, Pedro e Denise, minha base, sem eles não seria nada. Todo o amor, carinho, dedicação e, principalmente, compreensão que tiveram comigo nesses longos sete anos de faculdade. Por sempre proporcionarem o melhor para mim e me incentivarem a atingir as metas traçadas. São meus exemplos e não há homenagem que demonstre o amor que sinto por vocês. Obrigado por sempre confiarem em mim!

Aos meus avós maternos, Conceição e Elpídio, por me darem os melhores conselhos, nas horas mais apropriadas e me ajudarem a crescer pessoal e profissionalmente.. Aos meus avós paternos, meus anjos da guarda, Justina, que infelizmente não pôde acompanhar minha vida acadêmica por completo e Francisco, que não conheci, mas que é uma pessoa inspiradora, pelas suas histórias de caridade aos necessitados e trabalho árduo. A minha tia avó, Maria, que com seu coração e olhar meigo, me passou calma e foco nas horas de maior necessidade.

As minhas tias, Lúcia, Deolinda e Dolores, aos meus tios Francisco e Domingos e meus primos Douglas, João Vitor, Kelvin, Kaio e Vitória, pelo suporte familiar e pela torcida. Essa vitória é nossa!

A minha namorada, Flávia por todo o amor e apoio que me deu nos momentos de troca de curso e criação dos meus empreendimentos. Além de toda a compreensão quando eu não podia sair por imprevistos profissionais, familiares ou quando precisava fazer a monografia. Te amo!

Aos meus amigos do grupo Galãs da Tijucá, por fazerem parte da minha vida desde os tempos de escola e por participarem de histórias inesquecíveis, e também ao grupo do prédio Bola, que apesar do distanciamento, fizeram parte da vida acadêmica.

Aos meus grandes amigos de faculdade, Antônio e Pedro. Sem vocês as aulas teriam menos graça, a PUC seria menos valiosa e meus dias não seriam os mesmos. 
A minha professora, Alessandra Costa que sempre confiou no meu potencial e me ajudou da melhor forma possível a concluir essa etapa da minha vida acadêmica. E a minha primeira professora do curso de Administração, Gladys Trindade, que me ensinou os fundamentos que todo o administrador precisa ter, exigindo uma dedicação e aprimoramento constante em todos os projetos. Além dos conselhos e lições que levarei por toda minha vida.

Por fim, a todos aqueles que fizeram parte da minha longa jornada acadêmica e do início da minha vida profissional, com um conselho, uma dica, um abraço, uma pergunta ou um sorriso. Uma nova etapa da minha vida começa, todo o esforço valeu a pena. 


\section{Resumo}

Brazão, Flávio. Costa, Alessandra de Sá Mello da. Empreender em Favelas? Vantagens e Desvantagens na Perspectiva de Empreendedores da Rocinha. Rio de Janeiro, 2015. Número de páginas p. 54 Trabalho de Conclusão de Curso - Departamento de Administração. Pontifícia Universidade Católica do Rio de Janeiro.

O presente trabalho é de natureza qualitativa e tem como principal objetivo identificar, a partir do discurso dos empreendedores da Rocinha, as vantagens e desvantagens competitivas em ter empreendimentos na comunidade. Para alcançar esse objetivo, foram feitas cinco entrevistas com empreendedores locais de diferentes ramos de negócio. Todas as entrevistas foram gravadas e transcritas. Os dados coletados foram analisados tendo como base as seguintes categorias: (1) motivações, (2) características do empreendedor, (3) empreendedorismo, (4) vantagens e desvantagens de empreender na comunidade, (5) localização geográfica, (6) descoberta, avaliação e exploração de oportunidades, (7) diferença entre empreender dentro e fora da comunidade, (8) expandir ou criar novos negócios e (9) avaliação das políticas públicas na comunidade. Os resultados mostraram que os empreendedores entendem que, apesar de existirem algumas desvantagens, como falta de infraestrutura e o conflito entre tráfico e polícia, empreender na Rocinha é uma boa oportunidade, tendo como vantagem o baixo investimento inicial, o crescimento do consumo interno e a ausência de processos burocráticos inerentes a qualquer negócio.

\section{Palavras- chave}

Empreendedor, empreendedorismo, vantagens competitivas, desvantagens competitivas, empreender na favela, comunidade, Rocinha, oportunidades, percepção do contexto. 


\section{Abstract}

Brazão, Flávio. Costa, Alessandra de Sá Mello da. Empreender em Favelas? Vantagens e Desvantagens na Perspectiva de Empreendedores da Rocinha, Rio de Janeiro 2015. Número de páginas p.54 Trabalho de Conclusão de Curso - Departamento de Administração. Pontifícia Universidade Católica do Rio de Janeiro.

This study is qualitative and aims to identify, based on the reports of the Rocinha entrepreneurs, the competitive advantages and disadvantages in undertake in the community. To achieve this goal, five interviews were made with local entrepreneurs in various types of business. All interviews were recorded and transcribed. Data were analyzed based on the following categories: (1) motivation, (2) entrepreneurial characteristics, (3) entrepreneurship, (4) advantages and disadvantages of undertake in the community, (5) geographic location, (6) discovery, evaluation and exploration opportunities, (7) difference between undertake within and outside the community, (8) expand or create new business and (9) evaluation of public policies in the community. The results showed that entrepreneurs understand that although there are some disadvantages as lack of infrastructure and the mostly because of the low initial investment and other advantages, as the growth of domestic consumption and the absence of bureaucratic processes that is found in any business.

\section{Keywords}

Empreendedor, empreendedorismo, vantagens competitivas, desvantagens competitivas, empreender na favela, comunidade, Rocinha, oportunidades, percepção do contexto. 


\section{Sumário}

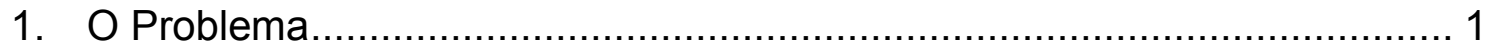

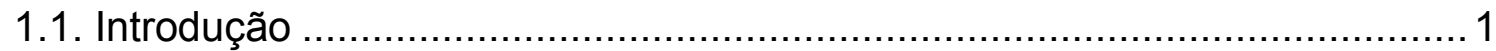

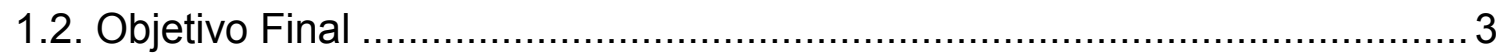

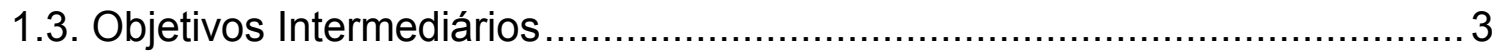

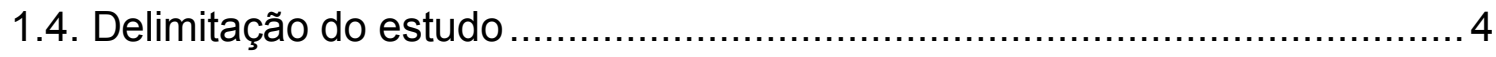

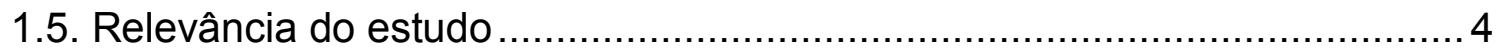

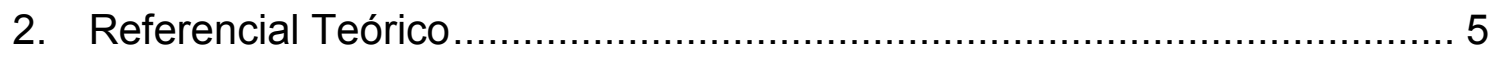

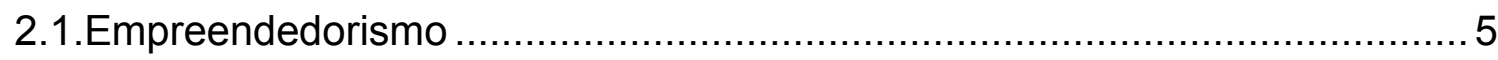

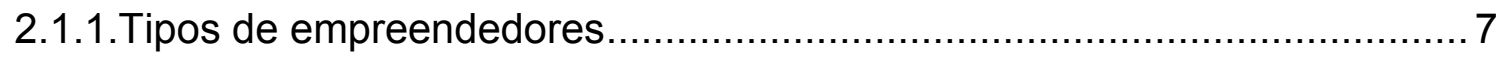

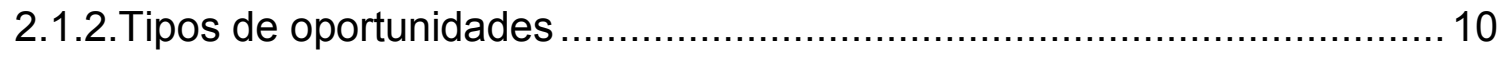

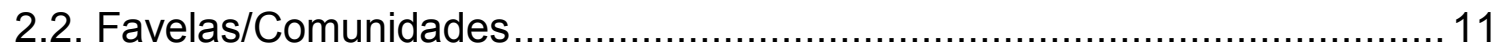

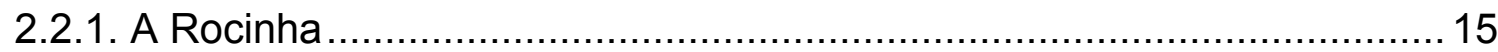

2.2.2. Ambiente e cultura na favela ......................................................... 15

2.2.3. Oportunidades de novos negócios nas favelas ................................... 16

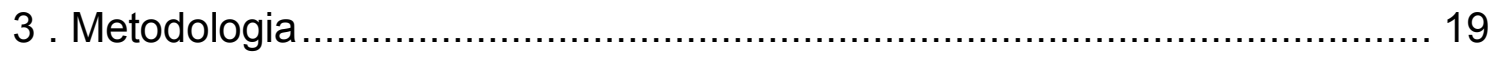

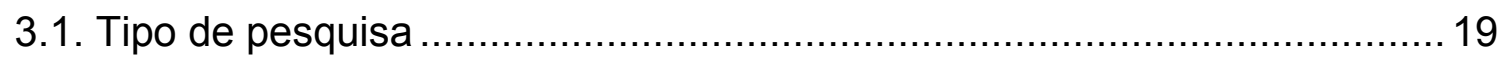

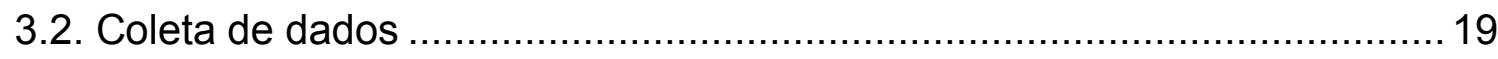

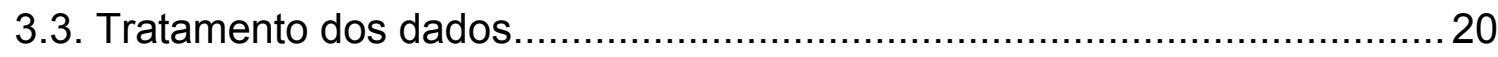


3.4. Limitações da pesquisa

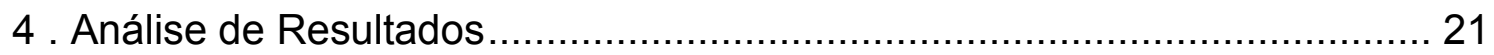

4.1. Pedro - O Empreendedor Nato ....................................................... 21

4.2. Leandro- Empreendedor Busca do Milhão .......................................... 24

4.3. Vitor - O Empreendedor Meu Jeito ................................................. 28

4.4. Mariana - A Empreendedora Nata e Herdeira ......................................... 31

4.5. Antônio - O Empreendedor Nato e Herdeiro ............................................ 35

4.6. Aproximações e Afastamentos nos Discursos Analisados ......................... 38

4.7. Vantagens e desvantagens percebidas .............................................. 40

5 .Conclusão e recomendações para novos estudos ..................................... 42

5.1. Sugestões e recomendações para novas pesquisas .............................. 44

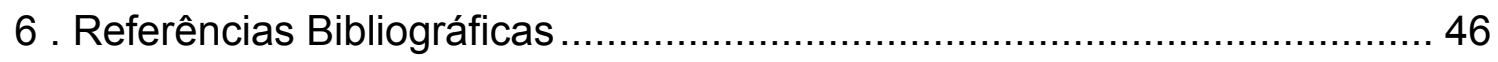

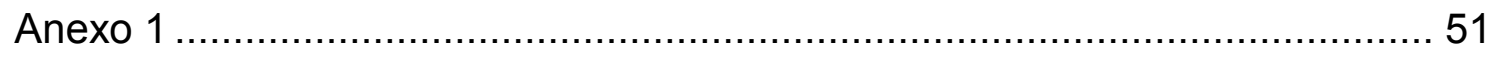

\section{Lista de tabelas}

Tabela 1: Empreendedores iniciais (TEA) segundo a motivação - Região

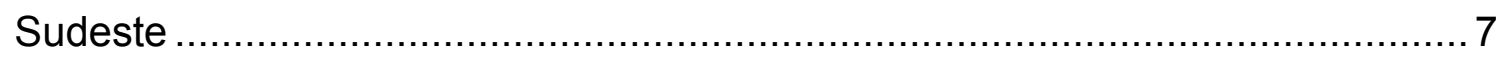

Tabela 2: Taxas de empreendedorismo segundo estágio dos empreendedores -

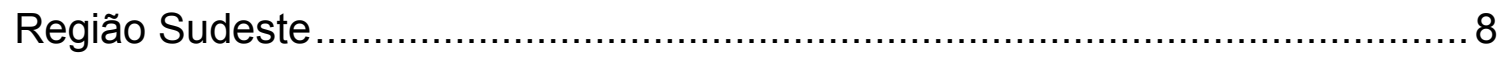




\section{O Problema}

\subsection{Introdução}

A cidade do Rio de Janeiro tem despertado a atenção do mundo com a realização de diversos eventos de grande relevância, como a Copa das Confederações em 2013, a Copa do Mundo em 2014, o Rock in Rio 2015 e as Olimpíadas em 2016. E ainda tem sido tema de diversas realizações cinematográficas de Hollywood, como Velozes e Furiosos 5 - Operação e a animação Rio 1 e 2, tem divulgado a cidade, trazendo turistas e investimentos.

De acordo com o anuário estatístico do Ministério do Turismo de 2014, ano base 2013, o Rio de Janeiro recebeu cerca de 2,5 milhões de turistas ao longo de 2013, um aumento de 4\% em relação ao ano anterior. Durante a Copa do Mundo de 2014, segundo a Riotur, a cidade recebeu 886 mil turistas, sendo 471 mil estrangeiros, gerando uma receita de 4,4 bilhões de reais e vale ressaltar que $98 \%$ dos que visitaram a cidade pretendem voltar e recomendarão como destino. Isso demonstra que o setor de serviços é uma boa oportunidade para os empreendedores, já que os números de turistas nacionais e estrangeiros estão aumentando anualmente.

Essa exposição e aumento da demanda têm refletido, principalmente, nos imóveis no Rio de Janeiro, que têm se valorizado acima da média nacional, de acordo com o índice FIPEZAP, da Fundação de Instituto de Pesquisas Econômicas (FIPE, 2014). A cidade foi a única em todo o Brasil que teve aumento superior a $1 \%$ em relação à inflação no valor do metro quadrado dos imóveis em fevereiro de 2014. Essa valorização tem afetado os alugueis na cidade, principalmente os comerciais nos pontos estratégicos, como Zona Sul e Centro.

Com isso, a taxa de abertura de novos negócios tem diminuído nesses locais, uma vez que, em geral são cobradas luvas, aumentando consideravelmente o investimento inicial. E, como é visível para a maioria da população, diversos empreendimentos 
tradicionais estão fechando, culpando os exorbitantes reajustes dos aluguéis, elevando o custo fixo e inviabilizando a continuidade.

Ao mesmo tempo, a cidade do Rio de Janeiro tem a maior população de favela do Brasil. Segundo estudo do Censo 2010, divulgado pelo Instituto Brasileiro de Geografia e Estatística (IBGE), são quase 1,7 milhões de pessoas distribuídas nas 1.000 favelas, sendo a Rocinha e o Rio das Pedras as que concentram maior número de habitantes. Graças ao programa das unidades de polícia pacificadora (UPP) do Rio de Janeiro, iniciado em 2008, que visa retomar os territórios invadidos por facções criminosas e principalmente integrar as comunidades à cidade, hoje já são 38 UPP’s instaladas, vem ocorrendo a criação e a ampliação dos negócios legais, mesmo aqueles não formais (MEIRELLES \& ATHAYDE, 2014).

Assim, as favelas tornaram-se uma grande oportunidade para os empreendedores (locais ou não locais), pelo crescimento constante de turistas e moradores da cidade, desejando visitar, conhecer a cultura, a rotina desses locais, além da vista da cidade (POPULAR, 2013). Essa intensa visitação, além de aumentar a autoestima dos moradores, acaba com diversos estigmas e atrai a ação do poder público.

Outro importante agente para o crescimento das atividades produtivas nas comunidades cariocas é o governo, por meio dos programas sociais, Programa de Aceleração do Crescimento (PAC) e Bolsa Família. O PAC é um programa estratégico que, através do investimento em infraestrutura, promove o desenvolvimento econômico da região, dando oportunidade para o investimento privado, gerando mais emprego e renda para a população local.

O Bolsa Família visa à transferência direta de renda, no qual beneficiam famílias de extrema pobreza e pobreza no país, de acordo com o Governo Federal os rendimentos mensais são de até $\mathrm{R} \$ 70$ por pessoa.Os beneficiários são escolhidos de acordo com as informações cadastradas pelos municípios no Cadastro Único para Programas Sociais do Governo Federal. O valor repassado varia de acordo com o tamanho, a idade e renda da família, que pode ter um acréscimo caso haja gestante, mães que estão amamentando, crianças e jovens até 17 anos. Apesar de todas as críticas e o uso eleitoreiro, o programa estimula a circulação do dinheiro, movimentando direta ou indiretamente os setores de produção. Segundo dados do Instituto de Pesquisa de Economia Aplicada (IPEA), essa política pública consome cerca $0,5 \%$ do Produto 
Interno Bruto (PIB). Contudo, cada real aplicado cresce 1,78 reais no PIB e soma 2,40 reais ao consumo das famílias (SECRETARIA DE ASSUNTOS ESTRATÉGICOS DO BRASIL, 2013).

Por todos esses fatores, os empreendedores locais, que sempre foram conhecidos pela criatividade e constante adaptação à demanda, estão crescendo cada vez mais e os empresários que, antes, jamais pensariam em ter qualquer atividade nesses locais, estão migrando (MEIRELLES \& ATHAYDE, 2014).

Na busca de melhor compreender essa dinâmica, a presente pesquisa teve a seguinte pergunta norteadora da pesquisa: Quais são as vantagens e as desvantagens percebidas por empreendedores locais em criar novos negócios nas favelas da cidade do Rio de Janeiro?

\subsection{Objetivo Final}

Este trabalho pretende identificar, a partir do discurso dos empreendedores locais, quais as vantagens e desvantagens percebidas em criar novos negócios na favela da Rocinha no Rio de Janeiro.

\subsection{Objetivos Intermediários}

- Proceder uma revisão bibliográfica no tema empreendedorismo a partir do recorte das oportunidades de novos negócios;

- Proceder uma revisão de literatura sobre o tema novos negócios nas favelas;

- Identificar nos discursos dos empreendedores locais que possuem (ou já possuíram) negócios na favela da Rocinha a história de sua trajetória empresarial.

- Identificar nos discursos dos empreendedores locais que possuem (ou já possuíram) negócios na favela da Rocinha o que eles entendem como oportunidades de negócios.

- Identificar nos discursos dos empreendedores locais que possuem (ou já possuíram) negócios na favela da Rocinha o que eles entendem como barreiras para os negócios.

- Comparar os discursos analisados de forma a identificar aproximações e afastamentos entre as percepções dos empreendedores. 


\subsection{Delimitação do estudo}

Apesar de o fenômeno estudado poder ser identificado e analisado em diversas áreas da cidade do Rio de Janeiro com características bem semelhantes, o presente estudo delimita-se a estudar tão somente a favela da Rocinha. Principalmente pela localização, que está perto da PUC-Rio (o que facilita o acesso aos dados), a região vem sendo alvo de interesse de estudiosos de diferentes áreas do conhecimento, tais como geografia, história, sociologia e administração (o que facilita o acesso a material bibliográfico).

\subsection{Relevância do estudo}

Este estudo é relevante para empreendedores que queiram abrir negócio nas favelas cariocas e para os que já têm, mas estão propícios a diversificar ou estender seus negócios, para que saibam os prós e contras de ter qualquer empreendimento nesse local e assim enxergar oportunidades ou adaptar seu produto/serviço a cultura da Rocinha. E para investidores que queiram entender melhor as estratégias corporativas e os principais players focados nessa região, além de estudiosos de empreendedorismo que desejem analisar as diferentes maneiras de se empreender na Rocinha do Rio de Janeiro.

Uma vez que a Rocinha é uma das maiores favelas da cidade, com uma economia interna sempre pulsante e apesar de não ter empreendimento fixo na Rocinha e tão pouco em outras favelas, acaba sendo relevante para mim, principalmente pelo fato da construção civil estar pulsante nessas regiões, na construção de novas ou na ampliação de existentes, devido ao desenvolvimento econômico. 


\section{Referencial Teórico}

\subsection{Empreendedorismo}

O empreendedorismo é um fenômeno multidisciplinar e complexo, pois utiliza métodos das mais variadas áreas, como Economia, Psicologia e Sociologia. Representa o desenvolvimento socioeconômico do país, além de uma nova forma de gestão empresarial, pela estreita ligação entre o Homem e o negócio (COSTA \& SARAIVA, 2011).

Segundo Venkataraman (1997 apud ECKHARDT \& SHANE, 2003) o empreendedor é movido pela descoberta, avaliação e exploração de produtos e serviços futuros, no qual dependerá da forma como eles serão introduzidos no mercado e a aceitação do público-alvo, para obter sucesso.

Nos últimos anos, a palavra empreendedorismo teve uma grande visibilidade e importância para a economia. Segundo Kuratko (2005 apud LOPES, 2010), cada vez mais nota-se um vibrante segmento de novas iniciativas levadas a cabo pelos empreendedores que ajudam no processo de renovação e de introdução de inovações tecnológicas, além de agregar pessoas ao mercado de trabalho, participar de exportações e gerar desenvolvimento econômico.

O Brasil é um país que, apesar de ter melhorado em diversos aspectos ao longo dos anos, ainda é dependente do mercado externo, que por sua vez, depende do investimento público, o que não acontece muito. Isso, entre outras ações não tão admiradas pelo mercado internacional, gera uma instabilidade econômica, que, conseqüentemente, afeta o mercado brasileiro, aumentando a inflação, e provoca a diminuição da produção, causando um aumento do desemprego. $\mathrm{E}$, muitas vezes, nessas situações ruins que as pessoas acabam criando seus pequenos negócios para se sustentar, é que surge um próspero empreendimento, são os praticantes da melhor versão do jeitinho brasileiro (MEIRELLES \& ATHAYDE, 2014). 
Essa explicação é uma das realidades sociais utilizadas por Davidsson para definir o empreendedorismo. Para ele, é o mercado que direciona o empreendedorismo; uma vez que a necessidade faz com que as pessoas criem novos valores, sejam (MELLO et al., 2010).

De acordo com Shane e Venkataraman (2000 apud MELLO et al., 2010), as oportunidades empreendedoras caracterizam-se como aquelas situações nas quais novos produtos, serviços, matérias primas ou métodos organizacionais podem ser introduzidos e comercializados a preços superiores aos seus custos. E essa decisão depende da característica do empreendedor em avaliar se o retorno esperado será bom o suficiente para que ele arrisque e se sacrifique em prol do objetivo traçado.

O dinamismo é intrínseco quando se empreende, pois em dado momento há a necessidade de focar no mercado e suas transformações, enquanto em outra ocasião é preciso dar mais atenção ao empreendedor e seu comportamento. Isso deve ao poder de influência que o indivíduo exerce na região, seja pelo desenvolvimento econômico local ou cultural. A interação entre esses dois protagonistas, empreendedor e sociedade, é constante, principalmente pelo valor criado pelo primeiro. Segundo Bruyat e Julien (2000 apud MELLO et al, 2010), a pessoa planeja a sua empresa de uma forma, desenvolve os meios de trabalho e administra de acordo com o planejado e de repente acontece algum fator, com o qual o empreendedor se vê obrigado a alterar o objeto do seu negócio. Esse fenômeno pode ser analisado sob quatro diferentes ângulos:

a) Reprodução empreendedora: pouco valor de criação, normalmente nenhuma inovação - pouco muda o individuo;

b) Imitação empreendedora: não há novo valor significativo na criação - o empreendedor muda seu know-how;

c) Valorização empresarial: há inovação e criação de novo valor significativo valorização das qualidades específicas da pessoa;

d) Empreendimento empresarial: quando eles mudam de forma radical o ambiente com a criação de um novo valor significativo, normalmente uma inovação que muda um setor econômico (MELLO et al, 2010).

Segundo o relatório Global Entrepreneurship Monitor (GEM Brasil 2013), o Brasil está à frente dos países dos BRICS, em relação à proporção de empreendedores 
iniciais por necessidade atingiu $28 \%$, enquanto os por oportunidade atingiu $71 \%$, esse percentual foi o mais elevado dos últimos 12 anos. A tecnologia tem ajudado a impulsionar o empreendedorismo por oportunidade no país, com o aumento do uso de smartphones nos últimos anos, aliado ao pequeno investimento inicial, facilitando a criação de aplicativos, entre outras soluções tecnológicas (SEBRAE, 2014).

Tabela 1: Empreendedores iniciais (TEA) segundo a motivação - Região Sudeste

\begin{tabular}{|l|l|l|l|l|l|l|l|}
\hline $\begin{array}{l}\text { Motivação do } \\
\text { empreendimento }\end{array}$ & Sudeste & \multicolumn{2}{|l}{ Taxa mais } & \multicolumn{2}{|l|}{$\begin{array}{l}\text { Taxa mais } \\
\text { baixa }\end{array}$} & Brasil \\
\hline & $\mathbf{2 0 1 3}$ & Região & $\mathbf{( \% )}$ & Região & $\mathbf{( \% )}$ & $\mathbf{( \% )}$ \\
\hline Taxa de oportunidade & 15,2 & Sudeste & 15,2 & Nordeste & 9,3 & 12,3 \\
\hline Taxa de necessidade & 4,9 & Norte & 6,4 & Sul & 3,0 & 5,0 \\
\hline $\begin{array}{l}\text { Razão } \\
\text { oportunidade/necessidade }\end{array}$ & 3,1 & Sul & 3,6 & Nordeste & 1,7 & 2,5 \\
\hline $\begin{array}{l}\text { Oportunidade como } \\
\text { percentual da TEA }\end{array}$ & 75,6 & Sul & 78,2 & Nordeste & 62,7 & 71,3 \\
\hline
\end{tabular}

Fonte: GEM Brasil 2013

De acordo com (CHIAVENATO, 2005), o empreendedor possui três características básicas: (1) possui uma necessidade de realização (os empreendedores apresentam alta necessidade de realização em comparação às pessoas gerais da população); (2) possui disposição para assumir riscos (o empreendedor tem preferência pelo risco moderado para iniciar seu próprio negócio); e (3) possui autoconfiança para enfrentar os desafios e problemas que surgem nos negócios.

\subsubsection{Tipos de empreendedores}

A criação de novos negócios deve-se ao clima favorável, uma visão positiva do empreendedor. Além disso, a palavra empreendedor é bastante cultuada na mídia, $56 \%$ dos entrevistados pelo Instituto Endeavor, concordam que viram muitas entrevistas e matérias sobre empreendedores na mídia em geral. "Esses fatores, somados à vontade de "ser dono do próprio nariz", tendem a favorecer a vontade empreender" (ENDEAVOR, 2014, p. 10). 
De acordo com o projeto Global Entrepreneurship Monitor (GEM Brasil 2013); existem dois tipos de empreendedores, os iniciais e os estabelecidos. Em relação aos empreendedores iniciais, estes podem ser divididos em:

- Empreendedores Nascentes - administram o seu próprio negócio, mas ainda não pagaram salário e nem receberam qualquer forma de remuneração por mais de três meses.

- Empreendedores Novos - são proprietários que já retiraram pró-labores e pagam salários por mais de três meses e menos de 42 meses.

No que diz respeito aos empreendedores estabelecidos, esses tem um empreendimento já consolidado, que paga salários e gera remuneração aos proprietários por mais de três anos e cinco meses (SEBRAE, 2014).

Conforme a tabela 2, a região Sudeste tem as maiores taxas de empreendedores iniciais, dos quais os novos têm o percentual mais alto do Brasil, com 14,7\%. Em relação às outras regiões, o mercado está mais propício à criação de novos negócios, uma vez que tem o maior percentual à média nacional, em todos os estágios.

Tabela 2: Taxas de empreendedorismo segundo estágio dos empreendedores Região Sudeste

\begin{tabular}{|l|l|l|l|l|l|l|}
\hline $\begin{array}{l}\text { Estágio do } \\
\text { empreendimento }\end{array}$ & Sudeste & \multicolumn{2}{|l|}{ Taxa mais alta } & \multicolumn{2}{l|}{ Taxa mais baixa } & Brasil \\
\hline & $\mathbf{2 0 1 3}$ & Região & $\mathbf{( \% )}$ & Região & $\mathbf{( \% )}$ & $\mathbf{( \% )}$ \\
\hline Empreendedores iniciais & 20,2 & Sudeste & 20,2 & Sul & 13,6 & 17,3 \\
\hline $\begin{array}{l}\text { Empreendedores } \\
\text { nascentes }\end{array}$ & 6,1 & Norte & 7,1 & $\begin{array}{l}\text { Centro- } \\
\text { oeste }\end{array}$ & 2,5 & 5,1 \\
\hline Empreendedores novos & 14,7 & Sudeste & 14,7 & Sul & 10,5 & 12,6 \\
\hline $\begin{array}{l}\text { Empreendedores } \\
\text { estabelecidos }\end{array}$ & 16,0 & $\begin{array}{l}\text { Centro- } \\
\text { oeste }\end{array}$ & 19,8 & Norte & 12,1 & 15,4 \\
\hline $\begin{array}{l}\text { Taxa Total de } \\
\text { Empreendedores }\end{array}$ & 35,7 & $\begin{array}{l}\text { Centro- } \\
\text { oeste }\end{array}$ & 36,3 & Sul & 28,6 & 32,3 \\
\hline
\end{tabular}

Segundo Meirelles e Athayde (2014), os moradores das favelas cariocas que têm empresa, em sua maioria, são jovens e empreendedores iniciais e criaram seu negócio principalmente por necessidade, uma vez que tiveram que interromper os estudos para trabalhar, a fim de ajudar a família financeiramente ou devido uma gravidez precoce, 
assim não puderam se colocar no mercado de trabalho. Outro aspecto relevante desses novos empreendedores é a relação de cooperação, pois aspiram crescer com suas comunidades (MEIRELLES \& ATHAYDE, 2014). Mesmo assim, diferentemente dos empreendedores que tiveram a oportunidade de ter uma formação ideal, que muitas vezes já estão colocados no mercado de trabalho, mas por quererem se realizar pessoalmente, acabam criando seus próprios negócios, após descobrirem uma oportunidade de mercado (SEBRAE, 2014).

$\mathrm{Na}$ pesquisa realizada pelo Instituto Endeavor, existem diversos perfis de empreendedores, apesar de não existir um perfil puro. Em geral cada empreendedor tem um perfil dominante, mas exibe características de outros.

- Nato - empreendedor que desde criança pratica atitudes empreendedoras, eles buscam realizar seus sonhos e procuram uma maneira para atingir essa meta. Em sua maioria são de origem humilde.

- Meu jeito - são pessoas que acreditam na forma que elas conduzem o negócio, independentemente do que os outros dizem e tem dificuldade de trabalhar em algo em que não acreditem. São de origem pobre, mas tiveram oportunidade de estudar, pois seus pais priorizaram os estudos.

- Situacionista - indivíduo que, diferentemente dos perfis anteriores que buscam empreender, acaba criando seu negócio, por surgir uma oportunidade à sua frente e agarrou-a, pois tinha vontade de arriscar e estava insatisfeito com o mercado de trabalho. Em geral fez faculdade, estava trabalhando para alguma empresa e surgiu a oportunidade de empreender.

- Herdeiro - ao longo de sua vida, foi habituado no meio de empreendedores, portanto tem experiência no meio do empreendedorismo e assim resolve ter seu próprio negócio, ou acaba administrando os negócios da família.

- Idealista - é um perfil que tem nos seus valores e idéias, a base para empreender, tem como objetivo principal a melhoria da comunidade $e$ impactar efetivamente a sociedade. O lucro é bom, mas não primordial.

- Busca do milhão - visa o lucro primordialmente, pois empreende para alcançar fortuna. Já estavam com uma boa posição no mercado de trabalho, mas como são ambiciosos, preferiram empreender para ganhar 
mais dinheiro num espaço menor de tempo. Esse perfil é percebido na maioria dos empreendedores brasileiros (ENDEAVOR, 2014).

\subsubsection{Tipos de oportunidades}

Oportunidade e empreendedorismo são palavras que estão bastante associadas, afinal há uma constante influência entre elas. Existem duas vertentes entre os autores sobre oportunidades no mercado, para alguns as oportunidades estão no mercado e, inúmeras variáveis, acabam surgindo e são descobertas por pessoas que tem características ímpares, que são os empreendedores. Enquanto para outros autores, as oportunidades são criadas pelos empreendedores, mas para isso esses precisam ser criativos e terem influência no mercado em vista.

Dessa forma, descobrir oportunidades implica entendê-las como sendo realidades objetivas que existem no ambiente empresarial e são descobertas, em função das características individuais e experiências vividas pelos empreendedores (SUDDABY, BRUTON, \& STEVEN, 2015). Por outro lado, criar oportunidade implica em entender as oportunidades como atos endógenos e iterativos de criação em que o empresário socialmente constrói tanto a oportunidade como o produtos ou serviço (SUDDABY, BRUTON, \& STEVEN, 2015).

Entretanto, independentemente da oportunidade ser criada ou descoberta, elas podem ser diferenciadas quanto o seu aproveitamento, afinal podem ser complexas ou simples; com retorno de curto, médio e longo prazo; necessitam de um pesado investimento inicial ou não. A oportunidade mais comuns - criação de uma comunidade, logo haverá a necessidade de produtos e serviços perto para suprir a demanda local. A Oportunidade mais restrita - num determinado mercado ou empresa houve a necessidade de um serviço ou produto para concluir o projeto, portanto alguém desse meio pode aproveitar e atender essa ausência. Por fim, a oportunidade inovadora - surge de uma visão diversificada das demais, onde nem sempre são óbvias as necessidades de um negócio, é uma oportunidade criada a partir de uma idéia totalmente nova ou um nicho de mercado (CONGLOMERADO, 2015). 


\subsection{Favelas/Comunidades}

Para entender melhor os aspectos intrínsecos na formação da favela, é necessário entender o que caracteriza uma favela, como foi sua criação, as etapas ao longo dos anos e principalmente como é hoje. Atualmente, a definição oficial considerada pelos censos, é um conglomerado de 50 ou mais barracos, que pode ou não ter uma disposição ordenada; construção precária e o tipo de aglomeração desenvolvido fora da lei (VALLARDES, 2000).

O surgimento das primeiras moradias populares que vieram a se caracterizar como favela, foram os cortiços, barracos e habitações precárias no século XIX. Esses locais serviam de moradia para trabalhadores, vagabundos e malandros. $O$ terreno desses cortiços era invadido e como seus ocupantes eram muito pobres, não tinham condições de investir numa melhoria dos barracos e do espaço, possibilitando a proliferação de doenças. Os principais interlocutores da época caracterizavam os personagens dos cortiços a criminalidade, local de meretrizes, feiticeiras, gerando um preconceito da sociedade em geral. Assim, o governo Barata Ribeiro resolveu adotar algumas medidas contra esse "mal" da cidade. A primeira delas foi impedir a construção de novos cortiços e a destruição do mais importante, o Cabeça de Porco (VALLARDES, 2000).

Tempos mais tarde, com o aumento da desigualdade social e a dificuldade burocrática de acesso à moradia, são fatores explicativos ao apelo da favela, da qual se iniciou com o Morro da Favella, que servia de habitação para antigos combatentes da Guerra dos Canudos que se instalaram nesse local para pressionar o governo a pagar seus salários atrasados. Essa denominação ao longo do tempo foi se estendendo a qualquer conjunto de barracos aglomerados sem traçado de ruas, nem acesso aos serviços públicos, sobre terrenos públicos ou privados invadidos (VALLARDES, 2000).

$\mathrm{Na}$ cidade do Rio de Janeiro desde o inicio do século XX, as palavras "favela" e "morro" são consideradas sinônimas, que significam hábitat pobre, de ocupação ilegal e irregular, sem respeito às normas e geralmente sobre encostas. Essa denominação por diversos fatores era associada como problema a ser resolvido para o desenvolvimento da cidade (VALLARDES, 2000). 
A revolução de 1930 foi um marco para as favelas, com a ditadura populista de Getúlio Vargas reconhecendo e protegeu os trabalhadores. O prefeito nomeado nesse período foi Pedro Ernesto que agiu de uma forma diferente das demais políticas públicas utilizadas anteriormente, pois reconhece a existência de favela como nota a necessidade de melhorar as condições de vida dos moradores desses locais e ainda ajuda as escolas de samba para o Carnaval, tornando a relação mais fluida (VALLARDES, 2000).

O ano de 1937 foi simbolicamente muito significativo, com a criação do Código de Obras, que pela primeira vez reconhece a existência da favela e a criação do então Instituto Social, hoje Departamento de Serviço Social da Universidade Católica do Rio de Janeiro (PUC - Rio), que teve um papel muito importante nos três parques proletários construídos para o realojamento das famílias que viviam em locais insalubres. O objetivo principal desses parques era dar assistência e educar os moradores para melhorar suas práticas, adequando-se a um novo modo de vida capaz de garantir sua saúde física e moral (VALLARDES, 2000).

Em 1945, Getúlio Vargas foi deposto e com isso a relação colaborativa com os moradores das favelas é interrompida e em 1949, é publicado um documento oficial com um discurso conservador e arcaico, na qual o objetivo principal dessa manobra é justificar o retorno da política de erradicação das favelas pela Prefeitura do Rio de Janeiro. A Igreja Católica nesse momento, com a Fundação Leão XIII tem um importante papel na defesa dos necessitados, desenvolvendo a produção de moradias novas e equipamentos de infra estrutura. Enquanto o jornalista Carlos Lacerda trabalha pela remoção. Uma vez que a construção civil começa a intensificar em Copacabana, as favelas ao seu redor começam a expandir, foi então que Lacerda conduz "A Batalha do Rio" junto à imprensa local, exigindo que os favelados sejam expulsos, que voltem para a zona rural e ações enérgicas para evitar a criação de novos conglomerados em outros pontos da cidade (VALLARDES, 2000).

Enquanto o ano de 1937 foi simbólico, o de 1950 foi considerado um marco na história da produção das representações sociais da favela carioca. Nesse ano ocorreu o Recenseamento Demográfico Geral e a produção do texto de Guimarães, no qual o autor conclui que nas favelas existe uma população ativa, predominantemente trabalhadora em diferentes tipos de mercado. Essa publicação invalida os discursos anteriores sobre a ociosidade dos moradores e a imagem pública das favelas do Rio 
de Janeiro jamais seria a mesma, as representações focam principalmente na valorização da favela quanto à comunidade; gerando um intenso debate político em relação ao destino delas. A comunidade já mostrava que conseguia se organizar coletivamente, junto às associações de moradores, mas ainda permaneciam dependentes de mediadores como à Igreja e agências públicas. As Nações Unidas corroboravam essa união das forças, a fim de integrar essas comunidades à cidade e assim desenvolver a economia da cidade (VALLARDES, 2000).

Contudo, de meados dos anos 60 até os 70, tendo como principal articulador o então governador do estado da Guanabara, Carlos Lacerda, durante o regime militar, ocorreu a eliminação e remoção das favelas da zona sul e Maracanã, para conjuntos habitacionais afastados da metrópole como Cidade de Deus e Vila Kennedy. O discurso para tal ação era que o crescimento desordenado das favelas prejudicava a paisagem da cidade e que esse projeto serviria de modelo para aplicação que outras cidades brasileiras. (MELLO, 2014).

Segundo o plano de Lacerda (1962-65), seguido por Negrão de Lima (1966-71) e depois por Chagas Freitas (1971-74), as favelas localizadas em regiões turísticas seriam removidas A primeira remoção a gerar debate e manifestação da Federação das Associações de Favelas do Estado da Guanabara (FAFEG) cuja palavra de ordem era “Urbanização sim, remoção nunca!", foi a favela do Pasmado. Independentemente disso, houve a remoção e para evitar a reocupação do local, Lacerda determinou a queima dos destroços. O que não se imaginava que essas operações levariam uma expansão das favelas que não eram ameaçadas pelo plano, por pessoas que não queriam ir para os conjuntos habitacionais e/ou não se adaptaram a essas moradias. Mesmo com todos os efeitos negativos a essa política, o governador se manteve firme e outras remoções se efetivaram até a metade dos anos 70, como; Favela Getúlio Vargas, Praia de Ramos e Praia do Pinto (MELLO, 2014).

Posteriormente a essas remoções, houve uma ausência de políticas públicas de efeito, mesmo com a expansão das favelas e isso era um desafio para qualquer planejamento, agravando os problemas sociais, gerados pela pobreza. Esse cenário contribuiu para o crescimento da violência em suas diferentes formas, o tráfico expandiu seus territórios, financiou os bailes funk e dominou essas regiões, de tal forma que as regras locais eram ditadas por eles, ampliando a sensação da cidade informal. Logo as favelas eram associadas ao comércio de drogas, somados esses 
fatores dificultavam qualquer ação do Estado, pois houve uma inversão de papéis, o tráfico era bem visto, enquanto o poder público não.

Em 1993, o Programa Favela Bairro, do prefeito César Maia em parceria com a Comlurb e a Cedae, mudou essa impressão. Enquanto os programas anteriores focavam nas moradias, esse visava à melhoria da infraestrutura, regulamentação imobiliária, serviços sociais e instalação de uma creche em cada favela urbanizada (VALLARDES, 2000).

Mesmo após a implementação do Programa Favela Bairro no final de 2008, na qual 168 favelas receberam melhorias, promovendo a integração da favela com a cidade formal, como os sociólogos diziam, o apartheid social se difundia, uma vez que os ricos não mediam esforços para proteger seus familiares e bens (VALLARDES, 2000). Porque apesar do programa do Estado ter sido eficaz, o principal problema que afasta a favela da cidade continuava sendo a violência. Afinal, o território tinha melhorado as condições de vida dessa população carente, mas o tráfico ainda ditava as regras locais.

Portanto, em 2008, inicia-se o programa das Unidades de Polícia Pacificadora (UPP) do Rio de Janeiro, que tem como objetivo retomar os territórios invadidos por facções criminosas ou milícias e assim promover a tão esperada integração entre as comunidades e a cidade. A primeira unidade foi instalada no Morro Santa Marta, em Botafogo e atualmente já são 38 UPP's abrangendo todo o Estado. Apesar de alguns problemas, o programa tem obtido sucesso, com a aceitação em geral dos moradores dos territórios ocupados e virou um modelo para o Brasil.

Simultaneamente, a economia local vem se desenvolvendo, com a criação e ampliação dos negócios formais ou não, integrando não só a cidade, como virando uma das principais opções para hospedagem de turistas, que antes só visitavam as favelas, por meio de empresas de turismo, como Favela Tour e JeepTour. Tanto que em 2006, um projeto de lei fez da Rocinha um dos pontos turísticos oficiais do Rio de Janeiro (FREIRE-MEDEIROS, 2009). 


\subsubsection{A Rocinha}

A Rocinha está localizada entre os bairros de São Conrado e Gávea, na zona sul do Rio de Janeiro. Apesar de ter diminuído nos últimos anos, acaba sendo um retrato da desigualdade existente no país (LOPES, 2009).

A favela surgiu com a chegada de portugueses e franceses nos anos 40. Anos mais tarde, essas encostas foram sendo ocupadas por imigrantes e moradores de outras favelas, que, com o plano de remoção das favelas (1962-74), viram na região uma alternativa para reconstruir a vida, uma vez que ela não estava no circuito turístico da cidade na época, portanto não sofreria qualquer mudança. A partir dos anos 60, houve um aumento considerável nos moradores, pela facilidade de locomoção, com a construção do túnel dos Dois Irmãos, entre outros motivos (SOUL BRASILEIRO, 2015). Seguindo esse crescimento populacional, o mercado interno foi se diversificando para suprir a demanda local. Atualmente a Rocinha é uma das favelas cariocas que possui maior gama de comércio e serviço, que se localizam principalmente no Largo dos Boiadeiros e Barcelos (LOPES, 2009).

Devido a sua localização, a Rocinha teve uma vantagem competitiva em relação às outras favelas, pois nenhuma outra teve tantos artigos e estudos publicados, gerando um reconhecimento internacional e o anseio de várias ONGs do mundo, todavia ela tem uma característica única a seu favor, a familiaridade confortável de seus moradores com a presença estrangeira (FREIRE-MEDEIROS, 2009).

\subsubsection{Ambiente e cultura na favela}

Quando se fala em ambiente e cultura das favelas, as principais pesquisas globais sobre esse tema tratam essas comunidades de um jeito singular. O que é um erro, pois, assim como os moradores de cada bairro tem atitudes e hábitos distintos, pois são influenciados pelo meio, as comunidades também, ou até mais, pois são ambientes em constante movimento, seja em seu crescimento vertical e horizontal ou de seus moradores (VALLARDES, 2000).

Diferentemente de grande parte dos residentes de condomínios, os moradores de favela conhecem, provavelmente, o vizinho e sua família pelo nome. A interação entre eles é alta, gerando alegria, diversão e contagiando a todos. Um fenômeno bem 
comum que traduz bem essa interação é o churrasco que pode ser feito na laje ou lugares públicos, por diversos motivos, entre eles o fortalecimento dos laços familiares, as amizades e até mesmo negócios (MEIRELLES \& ATHAYDE, 2014).

Outro fator importante no ambiente e na cultura nas favelas, é que os jovens moradores são mais escolarizados, por ser prioridade no investimento dos pais e por entenderem que isso pode ajudá-los no mercado de trabalho e no acesso a melhores condições. Além disso, buscam cada vez mais a capacitação, que é maior do que a população em geral, pois desejam ter uma vida melhor que a dos pais. Isso enfatiza alguns aspectos, descrito pela pesquisa do Instituto Data Popular, muitos dos jovens pesquisados demonstram interesse em abrir o próprio empreendimento, com a qual buscam um maior rendimento e liberdade para administrar o seu tempo. A Rocinha é de acordo com o Censo Empresarial 2010, a que tem proporcionalmente mais empreendedores, com 10,1\% (POPULAR, 2013).

Um elemento para entender essa população são as formas de expressão e de consumo, que hoje em dia estão interligadas. Nos anos 70 , o funk se desenvolveu por expor histórias de violência nas favelas, ao longo dos anos esse tipo de expressão passou a ter apelo sexual e já em 2008, surgiu o funk ostentação, que expressa essa ascensão social. Para muitos jovens o sonho maior é mergulhar no mundo do consumo, que antes era utópico,comprar um produto original é questão de orgulho e destaque entre os amigos (MEIRELLES \& ATHAYDE, 2014).

\subsubsection{Oportunidades de novos negócios nas favelas}

Segundo Venkataraman (1997, apud ECKHARDT \& SHANE, 2003), O empreendedor é movido pela descoberta, avaliação e exploração de produtos e serviços futuros, que dependerá da forma como eles serão introduzidos no mercado e a aceitação do público-alvo, para obter sucesso Descobrir oportunidades é uma ação objetiva que deriva de choques externos às indústrias já existentes, ou seja, elas surgem independentemente das ações daqueles que já estão estabelecidos no mercado e procuram gerar lucro. Esses choques podem ser causados por mudanças nas variáveis tecnológicas, demográficas, mudanças de hábitos do consumidor, entre outras, que influenciam o mercado (ALVAREZ \& BARNEY, 2010). 
Qualquer indivíduo pode ser um empreendedor, basta ele estar alerta ao ambiente, para descobrir essas oportunidades e querer arriscar, essa característica é intrínseca a qualquer empreendedor (ECKHARDT \& SHANE, 2003). Em suma descobrir uma oportunidade é um evento, já explorar essa oportunidade pode ser um processo. Para diminuir o seu risco, cada um tem a sua maneira de buscar informações sobre o mercado, seja por métodos acadêmicos e/ou com pesquisa de campo, na qual buscará informações daquele produto/serviço e a região que ele instalará o seu negócio (ALVAREZ \& BARNEY, 2010).

A situação nesses locais mudou consideravelmente para melhor nos últimos anos, graças ao poder público, que investiu em saneamento básico, segurança e programas assistencialistas. Antes grande parte do comércio das favelas era movimentado pelos bailes funks e aquecido pelo tráfico de drogas, com a presença do Estado nessas áreas hoje pacificadas, esses dois vetores diminuíram, o que aumenta a responsabilidade e o desafio do setor público a substituir esse poderoso motor econômico local (MEIRELLES \& ATHAYDE, 2014). Todavia há a necessidade de indivíduos que produzam riqueza, criem e aproveitem oportunidades, melhorem processos e inventem negócios, já que estão inseridos numa sociedade baseada em livre mercado (COSTA \& SARAIVA, 2011).

Em função das produções cinematográficas e televisivas retratarem o tema favela para o mundo, os turistas passaram a procurar experiências inusitadas, interativas. Observar e consumir objetos e práticas associados aos moradores desses locais e empresas de turismo, como Favela Tour e Jeep Tour, foram as que enxergaram a oportunidade de suprir essa demanda crescente. Entretanto essa forma de turismo foi muito criticada, pois promove complicadas articulações entre lazer e miséria, uma vez que os moradores são vistos como animais em um zoológico e os turistas como máquinas de dinheiro. Seus defensores afirmam que a prática desse turismo desenvolve a consciência social dos turistas, a autoestima das populações receptoras e acelera a economia local, apesar que crescimento econômico, não é sinônimo de igualdade social, ainda mais que muitas das vezes os moradores não usufruem diretamente dos benefícios gerados (FREIRE-MEDEIROS, 2009).

Independentemente de ser a favor ou não desse tipo de turismo, o fato é, que ele iniciou a exploração do turismo nessas regiões e, com o desenvolvimento da economia local, os turistas agora têm opção de se hospedar nas favelas, tendo uma experiência 
heterogênea, pois conseguem interagir com a cultura local e viver o ambiente (FREIRE-MEDEIROS, 2009). E somado a diversos fatores, como a pacificação e acesso ao crédito, ajudou na interação da cidade, com a criação e ampliação dos negócios, sejam eles formais ou não (MEIRELLES \& ATHAYDE, 2014).

As comunidades do sudeste do país geram por ano 32 bilhões de reais. Dentre esse valor, as cariocas movimentam 13 bilhões de reais. Além disso, um dado que atraiu os empresários, principalmente os de varejo e prestação de serviços, é que mais da metade dos moradores consomem nas comunidades ou em bairros próximos (POPULAR, 2013). Esses mercados em crescimento criam-se nichos, assim como a oportunidade de se especializar (ECKHARDT \& SHANE, 2003).

Os moradores, que antes viviam severas restrições e privações, devido a essas melhorias tiveram uma ascensão social, tendo acesso ao crédito.O que ampliou admiravelmente a economia de consumo,ratificado pelo Instituto de Data Popular, no fim de 2013, 65\% dos moradores das favelas pertenciam a classe média, diferente de 2003, quando o percentual era de $33 \%$. No primeiro momento as empresas de grande porte, principalmente as de bens duráveis migraram para lá, afinal a dona de casa não queria mais lavar roupa no tanque, uma vez que ela podia parcelar uma máquina de lavar e assim não prejudicar a sua renda (MEIRELLES \& ATHAYDE, 2014).

Um desafio para os empreendedores que queiram se inserir nessas comunidades, de uma forma eficiente e duradora, é a necessidade de ouvir, respeitar e figurar como parceiro, entender que o protagonista sempre será a favela. Quando se negocia com um morador de favela, equivale na maioria das vezes, por causa da alta interação, a negociar com todos e cada comunidade precisa ser examinada de acordo com sua singularidade (MEIRELLES \& ATHAYDE, 2014). 


\section{Metodologia}

\subsection{Tipo de pesquisa}

De acordo com Vergara (2014), a pesquisa pode ser classificada quanto aos fins e quanto aos meios. Quanto aos fins, a pesquisa é descritiva, uma vez que visa expor percepções e expectativas dos empreendedores da e na favela da Rocinha. Quanto aos meios, a pesquisa é de campo e bibliográfica. De campo, porque foram coletados dados a partir de entrevistas presenciais com os empreendedores. A investigação também foi bibliográfica, uma vez que foi realizada uma pesquisa sobre o assunto em livros, revistas especializadas, jornais e artigos a fim de enriquecer ao máximo a análise.

\subsection{Coleta de dados}

Na pesquisa bibliográfica buscou-se informações em livros, dissertações, teses, artigos, internet e periódicos. Como resultado dessa pesquisa, foi obtido um conhecimento maior do empreendedorismo, de oportunidades de negócios, do ambiente e cultura da favela da Rocinha.

No que diz respeito às entrevistas, foi montado um roteiro não estruturado de perguntas (anexo 1) que serviu para coletar os discursos de 5 empreendedores da favela da Rocinha (ver Quadro 1 abaixo) de forma a entender as estratégias e os principais aspectos que levaram esses empreendedores a abrirem negócios na favela.

O acesso aos entrevistados se deu, por conhecer Pedro e Leandro, que foram os primeiros entrevistados e indicaram seus conhecidos que empreendem na Rocinha. Pedro indicou o Vitor e Mariana, e Leandro, o Antônio, por conhecerem a história empreendedora deles e identificaram que seriam úteis para a pesquisa. 
Quadro 1: Perfil Entrevistados

\begin{tabular}{|l|l|l|l|}
\hline Nome & Idade & Negócio & Escolaridade \\
\hline Pedro & 24 anos & Pet Shop & Ensino Superior Incompleto \\
\hline Leandro & 33 anos & Moto Taxista & Ensino Médio \\
\hline Vitor & 32 anos & $\begin{array}{l}\text { Galerista e Artista } \\
\text { Plástico }\end{array}$ & Ensino Médio \\
\hline Mariana & 27 anos & Comerciante & Ensino Superior \\
\hline Antônio & 28 anos & Mecânico de Moto & Ensino Superior Incompleto \\
\hline
\end{tabular}

Fonte: Própria

A finalização dessa pesquisa foi uma análise cruzada dos discursos dos cinco empreendedores, tendo como base as seguintes categorias: características do empreendedor, perfil do empreendedor, empreendedorismo, motivações, descoberta, avaliação e exploração de um novo negócio, vantagem e desvantagem de se empreender na Rocinha, localização geográfica, diferença entre empreender na favela e fora, políticas públicas, UPP e expansão do negócio.

\subsection{Tratamento dos dados}

Todas as entrevistas foram gravadas e transcritas. Após este processo, os dados foram analisados.

\subsection{Limitações da pesquisa}

Algumas limitações da pesquisa podem ser apontadas. Primeiro, em função do pouco tempo disponível para conceder a entrevistas, os entrevistados podem ter optado por responder às perguntas feitas de forma mais parcial. Também número de entrevistados não permite visualizar de forma mais profunda, possíveis aproximações e afastamentos entre os discursos identificados e analisados. Por fim, pela pesquisa ser qualitativa, não espera-se que os seus resultados sejam generalizáveis para outras comunidades e/ou outros empreendedores em contextos diferentes 


\section{Análise de Resultados}

A partir das respostas coletadas e depois analisadas, pode-se conhecer um pouco mais sobre (a) a história da trajetória empresarial e a realidade dos empreendedores locais da Rocinha; (b) o que eles entendem como oportunidades de negócios, as suas motivações, os seus planejamentos, as suas principais ações administrativas; e (c) como fazem para alcançar o sucesso, superando barreiras e sendo reconhecidos pela comunidade. Assim, a partir das aproximações e afastamentos entre as percepções dos empreendedores foi possível identificar algumas vantagens e desvantagens em criar novos negócios nas favelas da cidade do Rio de Janeiro

\subsection{Pedro - O Empreendedor Nato}

O entrevistado percebe-se como um empreendedor nato. Pedro tem uma Pet Shop na Rua 1, uma das mais movimentadas em toda comunidade, chamada Pet Shop R1. Foi iniciada pelo seu pai, que já utilizava o espaço como bar e, por problemas de saúde e buscando uma qualidade de vida melhor, transformou o local. Um dos entusiastas nesse novo empreendimento foi seu filho Pedro, que desde o começo administra o local.

Para ele, empreendedorismo é o meio no qual a pessoa busca dinheiro, para sobreviver, ainda mais quando ela não tem formação nenhuma, ou seja, não tem opção, entre empreender ou ser empregado em alguma empresa. Em sua opinião qualquer um pode empreender, embora que para isso, o indivíduo precisa ter consciência que principalmente no começo ele precisará abdicar de tudo e se esforçar bastante:

"porque ele fica atrelado, é muito difícil separar o pessoal do profissional, ou seja, ele pensa constantemente em formas de desenvolver o negócio e preocupação com o fornecedor. Desde quando trabalhei na pet, eu nunca trabalhei menos de 12 horas, diferente de uma carga normal de empresa que são 8 horas". 
São características comuns a todo empreendedor ser esforçado, persistente e detalhista, dado que os consumidores estão mais exigentes:

"Ele (consumidor da favela) quer atendimento e um produto com uma boa apresentação. Diferente de antigamente que ele tinha que se satisfazer com o que tinha. Pois tinha escassez de produto e então aceitava o que era oferecido. Agora ele tem acesso a serviços e produtos externos (asfalto) e com isso ficou mais exigente".

Além de ter essas características que julga ser necessárias ao empreendedor, ele se considera um, porque já houve momentos difíceis, nos negócios do pai e mesmo jovem buscou alternativas para manter a renda de casa, em conjunto com a mãe que era cozinheira, fazer quentinhas para ele vender nos Shoppings. A motivação para empreender vem principalmente da correlação entre esforço e remuneração, quanto mais você trabalha, maior será sua remuneração e consequentemente mais sucesso terá. Contudo outro fator importante é a independência, em relação ao horário de trabalho, no qual o próprio empreendedor é quem define.

Quanto à descoberta de uma oportunidade, ele acredita que depende da relação dessa pessoa com o meio. É primordial que a mesma pesquise as necessidades do local, note quais pontos são bons e se planeje para isso, afinal há um investimento inicial considerável:

"É uma questão da pessoa ficar atenta ao mercado, olhar as lojas que estão oferecendo para alugar ou vender e principalmente economizar dinheiro para aproveitar essas oportunidades, ainda mais hoje em dia que está mais caro".

Para avaliar o potencial do novo negócio o entrevistado busca informações sobre o mercado, gestão do novo empreendimento e se já existe algum estabelecido, além de fazer uma pesquisa com amigos e moradores da região, que por sua vez são muito úteis na exploração do empreendimento, na favela um método de divulgação, é o boca a boca.Esse mercado interno é visto como uma oportunidade e uma vantagem de se empreender na Rocinha, uma das maiores comunidades do Rio de Janeiro, com cerca de 200 mil moradores. Primeiro pelos moradores, em sua maioria, consumirem internamente, o que sustenta o mercado local, portanto a demanda é crescente e fiel. 
Segundo pela menor exigência em relação à burocracia para se criar e ter um negócio na favela, facilitando o empreendedor quanto aos custos

O baixo investimento inicial, comparado ao investimento nos outros bairros do Rio de Janeiro, também é considerado como uma vantagem. Apesar de a Rocinha ser considerada a favela mais cara para se empreender, por ser reconhecida internacionalmente e seu posicionamento geográfico, o que inflaciona o mercado de venda e locação. Contudo por esses motivos, é caminho para os fornecedores. O poder público facilitou esse acesso, asfaltando e alargando as vias de acesso, beneficiando a competitividade entre os fornecedores, aumentando o poder de barganha dos comerciantes:

"Nos últimos anos essas ações tiveram um papel importante. Mas na época do meu pai, elas tiveram um papel fundamental, pois a rua 1 não era nem asfaltada, não tinha saneamento básico, ou seja, quase nenhuma estrutura mesmo. O próprio desenvolvimento da favela em si, ajudou o negócio, com o asfalto, alargamento das vias, saneamento básico, facilitando o acesso de mais fornecedores, aumentando a competitividade entre eles, consequentemente o preço das mercadorias diminui".

Outro beneficio que as políticas públicas propiciaram ao empreendedor da favela foi o acesso ao microcrédito para o morador que quisesse criar um negócio na favela, com taxas muito abaixo do praticado no mercado, ajudando o desenvolvimento do local e das famílias. Entretanto a UPP, que trouxe alguns clientes externos, como da Gávea e São Conrado, teve um impacto,no geral negativo, no ponto de vista do entrevistado, uma vez que boa parte do dinheiro que circulava na Rocinha, era oriundo do tráfico, beneficiando o comércio local.

De acordo com o entrevistado, existem algumas desvantagens ao se empreender na Rocinha como o acesso ao crédito acima do microcrédito, uma vez que é necessário ir a um banco comum, que por sua vez exige algumas comprovações que emperra devido o negócio ser ilegal: 
"Outra desvantagem é o acesso ao crédito, que é limitado, acima de 15 mil é muito difícil, que esbarra na legalização do negócio e também a falta de uma estrutura financeira, a maioria dos clientes paga por fiado".

Outro obstáculo é no que se refere à expansão do negócio, considerado como algo inviável, independente da qualidade ou serviço que o empreendedor ofereça:

“(...) Então você não consegue expandir de uma forma lucrativa, os que tentam não são bem sucedidos".

Embora a expansão do negócio seja uma desvantagem, o aumento do ramo dos negócios é um objetivo traçado, com o qual ele já está buscando informações e se planejando para tal:

"Não temos projeção de expandir tanto fisicamente, como criar franquia ou algo do tipo, mas estamos avaliando em expandir os negócios, em outro ramo.Hoje, por exemplo, estou pretendendo expandir os negócios e abrir um albergue na Rocinha, para isso estou pesquisando muito sobre o assunto e conversando com alguns empreendedores que lidam com turistas".

\subsection{Leandro- Empreendedor Busca do Milhão}

O entrevistado percebe-se como um empreendedor em busca do milhão. Leandro trabalha na PUC desde 1999 e, com o salário, comprou uma moto para se locomover. Gostava de jogar videogame com os amigos nos momentos de lazer, mas como ninguém tinha o console, tinham que andar muito até uma loja na Via Ápia, que muitas vezes estava bem cheia. Os frequentadores eram de diversos locais da Rocinha, uns até mais afastados, era uma febre por videogames e jogos online; foi a partir dessa percepção que surgiu a ideia:

"Porque naquele espaço ele dominava o mercado, não tinha ninguém. $E$ lá onde eu moro, perto do Bob's, ninguém tinha e quando chegávamos à loja, via que várias pessoas que estavam jogando eram de locais até mais distantes, como a Rua 1, que é o dobro da distância. Ai pensei que poderia fazer algo do tipo ali perto de casa, na rua 4. Na época havia 
uma febre por videogames (PS2) existia poucas lojas de games na época. Então me aventurei a abrir um negócio próprio, comprei os consoles (games), tv's, comprei madeira e fiz os balcões. Aluguei um pequeno imóvel e contratei dos ajudantes".

Para colocar a ideia em prática, analisou o que precisava comprar, entre consoles, televisores, prateleira para apoiar os equipamentos e escolheu um lugar para alugar num ponto estratégico, pois não existia concorrentes por perto. Como não tinha dinheiro, resolveu vender a moto e se arriscar no negócio. Para conseguir o melhor preço buscava em sites de compras de produtos usados e ia ao encontro dos vendedores, independente do quão longe era, dava um jeito pra chegar e voltar pra casa com as compras. No começo a Lan House foi um sucesso, mas como não podia se empenhar totalmente, pois trabalhava na PUC, o faturamento caiu e para não perder o dinheiro investido, resolveu vender tudo:

"Depois que abri, o negocio deslanchou só que como trabalhava na PUC, não tinha como administrar um negócio, que precisava da minha supervisão constante para que não houvesse trapaça. Entrava muito pouco mesmo durante a semana, no final do mês pagava tudo que precisava, mas só sobravam 50 ou 100 reais. Por isso preferi vender tudo, porque senão iria perder o dinheiro investido, porque os consoles ficariam obsoletos."

Além de trabalhar na PUC, atualmente tem uma moto e trabalha nas horas vagas como moto taxista dentro da Rocinha, Ele avalia ser um bom negócio, pelo fato de a comunidade estar num terreno bastante íngreme e as vans e ônibus demorarem muito ou até mesmo não chegarem a alguns pontos. Além desses motivos a favela é uma das mais populosas da cidade e grande parte dos trabalhadores precisa sair de manhã e retorna só à noite. Esse fator o ajuda bastante, pois consegue conciliar seu horário, que na universidade é de $10.30 \mathrm{~h}$ às $21 \mathrm{~h}$, enquanto como moto taxista são dois turnos, das $6.30 \mathrm{~h}$ as $10.15 \mathrm{~h}$ e das $21.30 \mathrm{~h}$ as $23.30 \mathrm{~h}$. Outro ponto importante para o ramo que ele atua, é a posição geográfica da Rocinha, pela proximidade com a Zona Sul e Centro, regiões aonde a maioria dos moradores trabalham:

"Hoje trabalho com moto taxi, numa comunidade de mais de 100 mil moradores, num terreno bastante íngreme. As pessoas voltam 
cansadas, sem falar das pessoas que precisam chegar mais cedo no trabalho. Elas acabam utilizando esse tipo de serviço por ser rápido e relativamente barato, o custo benefício é válido. (..) "Outro ponto, na Rocinha existe as ruas principais, onde passam todos os meios de transporte, mas existem também muitas vielas, que ônibus e vans não passam, então é uma vantagem pegar a moto taxi.Outro benefício é que o serviço de moto taxi se estende para fora da comunidade, o trajeto se flexibiliza de acordo com a necessidade do passageiro".

Por ter uma população muito grande a Rocinha, é um mercado atrativo para ele, uma vez que a maioria dos seus clientes são moradores, há algum tempo foi um pouco mais diversificado, os estrangeiros também utilizavam esse meio de transporte. Ele busca ter alguns diferenciais, para conseguir uma clientela cativa e crescente:

"Na verdade dependo somente deles. Para manter e atrair novos clientes procuro não correr muito, a maioria não curte velocidade, fico bem atento ao trânsito e os trato com muita educação".

Para ele empreendedorismo é trabalhar em uma ideia que é pouco explorada, a fim de ter uma renda extra. Acredita que as principais características de um empreendedor são determinação e força de vontade, porque se a pessoa não se esforçar, ela nunca conseguirá atingir suas metas e não busque alternativas para ter uma vida melhor. A principal motivação é oferecer uma vida melhor para a sua família, para que seus filhos tenham oportunidade que ele não teve.

Apesar de nunca ter empreendido fora da Rocinha, percebe que na comunidade não existe a quantidade de imposto e o empreendedor dependendo do ponto onde está estabelecido, não precisa pagar qualquer tipo de conta ou taxa. O que acaba sendo uma vantagem na criação de um novo negócio, pois em outros lugares da cidade o investimento inicial é alto, assim como a burocracia:

"Na Rocinha não há a quantidade de imposto que você paga em qualquer outro bairro, o empreendedor se quiser, não precisa pagar água e IPTU, dependendo do lugar você não paga nem a luz. O único gasto que vai ter é com o empregado e com a mercadoria que você vai 
comercializar. Mas acho que a diferença primordial é o investimento necessário e a questão da burocracia".

Quanto aos investimentos públicos na Rocinha, ele entende que no inicio da instalação da UPP, ocorreram alguns benefícios. O comanda da UPP que gerenciava e ditava as normas para os moto taxistas, houve um cadastramento e só poderiam trabalhar mil em toda a Rocinha e os selecionados precisariam seguir algumas regras, como regularizar a moto, os documentos e cada um só poderia dirigir a sua moto, o que impede a expansão do negócio. Por um tempo funcionou. Entretanto aconteceram alguns casos e a UPP deixou de ser rigorosa e hoje em dia liberou para outros trabalharem, portanto a concorrência aumentou:

"Depois da morte do Amarildo e outras questões de furto etc, a UPP perdeu o respeito. Então foi trocando o comando, saiu um major e entrou outro e o ultimo a entrar liberou todo mundo a trabalhar de moto taxista, contanto que tivesse carteira de habilitação e documento da moto em dia. Ai começou a encher mais e ficou mais difícil, mas mesmo assim ainda dá pra tirar um dinheiro".

Apesar de não poder expandir no ramo dele, ele comprou uma laje e está planejando construir duas casas para alugar, pois acredita ser um mercado onde a demanda é muito maior do que a oferta:

“E agora to avaliando outro negócio também. Vou construir dois apartamentos de $45 m^{2}$ cada, numa laje, para alugar. As pessoas têm duas necessidades primordiais, comer e morar em algum lugar, é o que você ganha dinheiro em qualquer lugar. Moradia é outra coisa, muita gente fica de olho nas casas que tão a venda ou para alugar, porque a Rocinha fica no centro de tudo, você tem ônibus pra Barra, Centro, daqui há um ou dois anos, vai ter metro, então você vai para qualquer lugar sem muita dificuldade. Por esse motivo está tudo muito caro". 


\subsection{Vitor - O Empreendedor Meu Jeito}

O entrevistado percebe-se como um empreendedor que faz as coisas do seu jeito. Vitor é de uma família de comerciantes, o convívio era direto com o empreendedorismo, conforme foi crescendo isso tornou-se uma cobrança, pois ele tinha mais oportunidades. A vontade empreender foi aumentando de acordo com as tentativas de negócios. Para ele empreendedorismo é ter uma ideia que atenda a um público alvo e com a exploração, consiga uma renda, Por isso ele acredita que todo empreendedor precisa ser ousado, não ter medo do risco:

"Envolve um risco, se fosse certo, todos fariam. Então é ir no incerto e tirar alguma coisa disso, a diferença estará nos que vão conseguir ter sucesso". (...) "Eu trabalhei em vários segmentos, eu sempre fui muito curioso". (...) "Fui aprendendo com a vida e tomando gosto cada vez que empreendia. O problema que não tive gosto de me preparar pra isso, por mais que eu viesse de uma família de empreendedores, fui aprendendo com os erros, a vida foi me moldando e até hoje estou aprendendo".

Por ser nascido e criado na Rocinha e, conviver diariamente na comunidade, percebeu que existia um público consumidor pulsante. Para aproveitar essa oportunidade, começou a vender óculos, roupas, bijuteria, entre outros produtos. Entretanto a concorrência e a desmotivação foram alguns obstáculos que se tornaram aprendizados. Ele acredita que essa prática, te proporciona um ensinamento mais valioso do que na teoria:

"Mas eu tive que aprender e fui aprendendo, tomando na cabeça e fui melhorando. Mesmo assim é muito válido, melhor do que saber na teoria, acho que aprende mais, porque existem coisas que você nunca espera, independente do cara ser fera na teoria. É aquele negócio de falar assim; "Eu acho que dá", mas agora eu tenho certeza do que da certo. Porque na verdade, tudo funcionava na base do desespero não dava pra fazer uma pesquisa de mercado, me planejar direito, que é o ideal. Mas as circunstancias era o que tinha. Tive que ir aprendendo, mas nunca desisti". 
$\mathrm{Na}$ moda da Lan House, resolveu abrir uma, mesmo não sabendo usar computador. Obteve sucesso, mas com o crescimento da concorrência, o negócio começou a ficar difícil e entendeu que deveria migrar para outro. Resolveu transformar o espaço em Sex Shop, mas o preconceito das pessoas era a maior dificuldade para criar uma clientela, apesar disso teve uma boa clientela:

"Diferente da Lan House, que foi no embalo, eu vi que tinham algumas dando certo e arrisquei. Já na sexy shop não, antes de começar a investir pesquisei um pouco mais, não fiz com o público alvo e sim de mercado e em volta. Mas me deparei com um tabu que envolve esse tipo de comércio. Então consegui até certo ponto fazer uma base de clientes, mas aqui acabou não vingando como pretendia”.

Para impulsionar o negócio resolver usar seu dom, e fez um desenho na parede, o que fez sucesso. Os vizinhos e amigos comentaram sobre e a reprodução ficou conhecida na área. Nesse momento, Vitor começou a buscar informações do mercado de arte e, para não se arriscar, resolveu dividir o espaço da Sex Shop com a galeria de artes, uma vez que a Rua 1 é uma via onde a circulação de turistas é constante. A galeria começou a surpreender com as vendas. $O$ reconhecimento por toda a comunidade e a projeção que ele pode ter para fora, foram fatores fundamentais para a sua especialização. Para que essa expansão se torne natural, ele tem feito parcerias com alguns guias:

"Na época da sexy shop fiz um desenho simples na parede e começou a repercutir muito, foi ai que comecei a pesquisar alguns artistas e percebi que esse trabalho eu poderia fazer. Eu sempre ignorei, eu sabia fazer, mas como as pessoas vão saber que eu sei fazer, se eu só falar que sei. E ai começou repercutir e eu colher bons fruto". (...) "Pelo fato de ter achado uma coisa que realmente gosto de fazer, foi muito natural. $E$ aproveitar um talento que tinha e eu mesmo não dava valor. Eu já nasci com esse dom de desenhar, mas também fiz um curso rápido de desenho, para me desenvolver". (...) "Outro ponto que não queria e por isso, acho que tenho feito sucesso tanto com o pessoal de fora, como o daqui, é que não pinto as paisagens comuns do Rio de Janeiro, já são batidas. Pretendia ter um diferencial dos outros e isso me diferencia dos meus concorrentes daqui e de fora da comunidade. As minhas pinturas 
são o espelho da minha personalidade”. (...) “Nunca tive essa ideia de montar uma coisa e fica engessado num lugar só, quero expandir, divulgar, ser reconhecido em toda favela e fora dela, não só como galerista, mas como o artista Vitor Nascimento".

Quanto à vantagem de empreender, a Rocinha é a diversidade de consumidores, pois cada um tem uma história, veio de algum lugar, portanto é uma comunidade muito plural. Por isso existe mercado para todos, ainda pelo fato de ser enorme. Entretanto o empreendedor precisa ter sua meta definida para ter sucesso. Para o caso dele especifico o reconhecimento da favela da Rocinha no cenário internacional também é uma vantagem, pois mais turistas acabam visitando, considerando potenciais consumidores e/ou divulgadores:

"Aqui tem todo o tipo de pessoa, da mais engraçada a mais seria, do gastador ao poupador, os extremos. E como a Rocinha é uma comunidade muito grande, tem publico pra todo mundo". (...) "Você sabendo o seu objetivo e tendo personalidade, vai ter consumidor em todo lugar".

Apesar desse público ser grande e variado, na interpretação do entrevistado, o desinteresse de moradores de outros bairros em conhecer a Rocinha e seu mercado acaba sendo uma desvantagem em se empreender lá, uma vez que essas pessoas poderiam ser potenciais clientes. Uma vez que a ida desses moradores está atrelada a trabalho, ou seja, é para um motivo específico, dificilmente para apenas consumir. Portanto apesar da Rocinha ter uma localização privilegiada e ser perto de diversos bairros da cidade, o distanciamento cultural é grande, apesar de estar mudando aos poucos. E um dos motivos para essa mudança foi a instalação da UPP em 2012, trazendo um pouco mais de paz e consequentemente a visitação, procura por passeios na Rocinha, aumentou visivelmente. Outro beneficio foi a mudança de agir de certos comerciantes que eram mais favorecidos por quem ditava as regras na favela:

"Muitos comerciantes tiravam dinheiro do tráfico direto ou indiretamente e essa mudança funcionou pro bem, porque essas pessoas tiveram que agir e mudar a forma de comercializar, de uma maneira que seja legal, junto a ajuda do governo que teve alguns projetos ao mesmo tempo para diminuir esse impacto. No geral foi um resultado bom, trabalhar no 
certo é sempre melhor". (...) "No meu caso fui beneficiado, depois da UPP vieram mais turistas, a confiança e segurança mudam. Eu lembro que antes o turista, via um sorriso com medo e tinham medo de olhar pro lado, encarar alguém. Agora eles continuam com medo, mas com proporção muito menor do que antes".

\subsection{Mariana - A Empreendedora Nata e Herdeira}

A entrevistada percebe-se como uma empreendedora nata e herdeira. Mariana tem um comércio de artigos femininos e perfumaria. Quem iniciou o negócio foi sua mãe, que é da Paraíba, veio para o Rio de Janeiro em busca de oportunidades, trabalhou em casa de família, depois foi balconista de supermercado e, por último, trabalhou numa lavanderia. Foi economizando dinheiro para realizar o seu sonho, de ter o seu próprio negócio. Quando conseguiu teve uma barraca de camelô na Rocinha, em que vendia brinquedo de criança. Não deu muito certo e, para complementar o que recebia, vendia roupa de porta em porta por toda a comunidade, pois percebeu que não existiam muitos comércios nesse ramo e podia oferecer algo melhor:

"Espelhou-se nas amigas que tinham lojas de roupa. E percebeu que por aqui na Rocinha não existia tantas, tem tempo isso, e as que existiam vendiam umas peças não tão bonitas e com uma qualidade não tão boa. Ela começou a ver com essas amigas os fornecedores e a buscar outros que ofereciam uma qualidade melhor, num preço acessivel".

A partir dessa percepção Mariana, começou a ajudá-la, enquanto uma ficava na barraca, a outra andava pela Rocinha, vendendo as roupas. O comércio de roupa foi crescendo e começaram a ser reconhecidas por todos, com as economias, conseguiram alugar uma pequena loja, depois o negócio foi gerando mais receita, até que conseguiram comprar outros pontos, além do local onde estão estabelecidas hoje em dia.

De acordo com a entrevistada, a descoberta de uma oportunidade pode surgir a partir de uma necessidade que a pessoa sente, podendo ser de algum produto ou serviço. E cabe a pessoa aproveitá-la, mas para isso, a pessoa precisa ser corajosa 
para colocar a ideia em prática e também trabalhadora para atingir a meta estabelecida, por acreditar que possui essas características, ela se considera uma empreendedora:

“O empreendedor se arrisca para concretizar sua ideia e ganhar dinheiro com ela, ou seja, ele é uma pessoa corajosa. Outra é batalhadora, o empreendedor sabe que seu sucesso é o resultado do seu trabalho e assim ele não para, busca meios de ganhar dinheiro e assim ter sucesso".(...) "Por exemplo, eu e minha irmã, lá em casa sempre consumiamos muitos produtos que vinham em frascos de vidro, e ficávamos com pena de jogar no lixo." (...) “Um dia minha irmã veio com uma ideia da internet, de luminárias, porta lápis, castiçal entre outras coisas, foi daí que começamos a trabalhar com isso e vender".

Um fator importante para qualquer empreendedor é a sua motivação, uma das principais razões para o indivíduo trabalhar ainda mais em busca da sua meta, para Mariana, o pretexto fundamental é não existir um chefe, o empreendedor é livre para buscar o sucesso da maneira que lhe convir:

"A principal motivação é você não trabalhar para outra pessoa, trabalhar pra mim mesma. Ganhar dinheiro sem precisar ter um chefe, ditando as regras. Com seu próprio negocio você pode fazer sua própria oportunidade".

Para avaliar e explorar o potencial do negócio, ela entende a necessidade de uma constante renovação dos produtos, para manter a credibilidade e a clientela. E para isso viaja, busca informações sobre o que está na moda, além da inclusão de novos itens, que poderão ser agregados a gama de artigos da loja, aumentando o faturamento:

"Trazendo novidades, minha mãe que viaja mais de nós. Afinal trabalhamos com moda e existem tendências, coleção, essas coisas. Então é muito necessário pro negócio, trabalhar com roupas atuais e isso passa uma credibilidade para o cliente. Toda vez que colocamos roupas novas na loja, a demanda aumenta bastante, toda mulher gosta de se produzir, estar bem consigo mesmo e aumenta o ego estar com 
uma roupa da tendência, da moda. Essa renovação é muito importante em qualquer ramo, seja ele comércio ou restaurante, com algum novo prato". "é aquilo a cliente está comprando roupa e como toda mulher gosta de um porta objeto ou às vezes precisa de um porta jóias, pra dar. $\mathrm{Ou}$ às vezes gosta da luminária ou de qualquer produto que fica no mostruário e assim ajuda no lucro, porque a margem é bem maior".

A burocracia é uma questão vital para qualquer empreendimento e existem diferenças entre empreender na favela e fora dela, pois na opinião dela, esse assunto não é prioritário para criar um negócio e até mesmo para que o mesmo funcione. Embora esse cenário esteja mudando:

"Acho que existe diferença burocrática, no asfalto o empreendedor precisa estar muito certinho com licenças, contrato e alvarás. Na favela não é exatamente assim, apesar de estar mudando. Aqui, por exemplo, nós trabalhamos durante muito tempo sem qualquer tipo de alvará, tiramos o CNPJ há pouco tempo".

Apesar de não morar mais na Rocinha, elas continuam trabalhando na comunidade pela alta densidade populacional, aonde a movimentação de pessoas é constante, gerando uma vantagem competitiva. Além disso, o fato de ser reconhecida mundialmente, pela posição geográfica estratégica, perto da zona sul, dos hotéis, acaba sendo uma oportunidade, pois há a movimentação de turistas, incentivando o comércio interno, assim há mercado para todos. Entretanto existem alguns problemas inerentes a favela, como a precariedade do saneamento básico e a dificuldade para se locomover em alguns pontos, impossibilitando um escoamento maior de mercadorias:

"A movimentação de pessoas durante o dia é muito grande e existem muitos moradores na comunidade". (...) "Na Rocinha você pode empreender com qualquer tipo de negócio, que vai ter sucesso, a demanda é muito grande, coisas que não tinham e de uns anos pra cá começaram a pipocar, bancos, lojas de departamento, grandes marcas, redes de lanchonetes. Muito raro alguém abrir um negócio aqui e fechar pela falta de clientela". (...) "Às vezes o esgoto rompe e fica aquela água suja escorrendo pela rua, onde todos passam, além do cheiro forte. $O$ saneamento básico é bastante ruim, quase não existe em algumas 
áreas. Aqui, por exemplo, que é uma rua muito movimentada, o acesso é difícil, é muito estreito, não passa carro, nem nada". (...) "se compararmos a Rocinha e Vidigal que são comunidades dentro da Zona Sul e o Rio das Pedras que é mais distante, o mercado nessas duas favelas se desenvolveu muito mais, aqui tem empreendimentos que focam nesse interesse do turista conhecer, vamos dizer que alguns são ligados diretamente ao turista, como hostel ou guias. Afinal os turistas procuram se hospedar na Zona Sul, que é mais reconhecida. Diferente do Rio das Pedras, onde já morei e não conheço nenhum pra esse público".

A desvantagem da Rocinha reconhecida pela entrevistada seria solucionada se houvesse uma atuação mais consistente do governo nesses locais. Apesar de admitir que existiu um período onde as políticas públicas surtiram efeito. O problema que elas não têm continuidade. E alguns projetos como a UPP, não são bem vistos, uma vez que não conseguiram retirar os traficantes da região. $O$ confronto pode acontecer a qualquer hora, é eminente e a sensação de insegurança é elevada entre os moradores, ainda mais depois de alguns casos de abuso policial:

"Para ser franca, não". (...) "Com o Whatsapp, nós recebemos muitos vídeos e áudios dos moradores, conhecidos e amigos mesmo, mostrando que a madrugada foi de tiro e até de dia. Às vezes parece que até piorou, é o confronto diário dos bandidos com os policiais, independente da hora". (...) "Esses dias eu tava indo embora, passaram uns policiais com as armas pra fora, vai que acontece alguma coisa, por isso a maioria se abriga nas lojas. Ontem mesmo bem no horário da creche, eles estão fazendo ronda e os pais precisam esperar, ninguém aconselha andar junto com os policiais e ai precisa andar muito devagar pra distanciar bem deles. É perigoso, melhor não arriscar, tanto que a mídia agora está falando mais a realidade, principalmente depois do caso do Amarildo". 


\subsection{Antônio - O Empreendedor Nato e Herdeiro}

O entrevistado percebe-se como um empreendedor nato e herdeiro. Antônio faz parte da segunda geração de empreendedores da sua família, o seu negócio começou com seu pai nos 80 , que ao ser demitido de uma mecânica, resolveu abrir a própria na garagem da casa, que ficava na Rocinha e inicialmente consertava carros e motos. Por ser criado nesse meio, o entrevistado começou a se interessar e acompanhar a rotina da mecânica, com o passar do tempo, já administrava junto ao seu pai. Em dado momento o negócio não foi tão bem e Antônio, precisou buscar alternativas para ajudar a renda de casa. Como na época, o mercado de Lan House na Rocinha estava em crescimento, resolveu se juntar com um amigo e abrir uma, num cômodo perto de sua casa, o negócio durou um ano:

"Acho que a minha maior inspiração foi meu pai, eu já nasci tendo a mecânica, fui criado ali. Então ele sempre foi o meu inspirador de continuar aquilo, ele sempre me ensinou, sempre tive muita liberdade em perguntar e para dar minha opinião, sugerir. Foi quem me incentivou a gostar daquilo e querer que eu continuasse". (...) "Foi um momento difícil e pensei em formas de ganhar dinheiro. E tive a ideia de unir duas facilidades que tínhamos: os computadores do meu amigo e a minha internet boa. Como conhecia o dono de um cômodo que queria alugar, ele fez um preço mais camarada pra gente. A gente enxergou uma oportunidade da época, não era comum as pessoas terem computador em casa e as Lan Houses que existiam ficavam longe e lotadas e achamos que existia público para a Lan por ali. E na época bombava os jogos online, RPG e CS e não era comum computador em casa, então as pessoas usavam pro dia a dia, estava iniciando essas questões de rede social e alguns usavam até pra pesquisa escolar".

Após essa época, um investidor ofereceu um aluguel para seu pai e buscaram outro endereço para a oficina, o que acharam era menor. Portanto resolveram se especializar apenas em motos, uma vez que o mercado de motos na Rocinha é crescente. O que o motiva a empreender, é trabalhar num negócio que gosta e ganhe dinheiro com isso, para buscar uma condição de vida melhor: 
(...) "eu gosto do que faço então minha motivação é que faço por amor mesmo e fundamental é a renda mesmo".

Para ele qualquer pessoa pode empreender desde que tenha uma idéia e faça de tudo para colocá-la em prática. Portanto algumas características são fundamentais para ele, como; ser proativo, corajoso, bom administrador e se doar ao negócio:

"Primeiro o empreendedor precisa ser proativo, porque não adianta ter a idéia e não colocá-la em prática. Então você precisa ter coragem para botar a idéia em prática. Segundo para a pessoa ser uma boa empreendedora, ele precisa ter um espírito de administrador, precisa planejar e saber tocar o negócio. Além de estar em tempo integral para controlar os funcionários e o que precisa fazer, senão o negócio fica frouxo".

No que diz respeito sobre a avaliação e exploração do negócio, ele acredita que o primeiro interfere no segundo ponto, pois senão houver uma avaliação consciente do negócio, que engloba pesquisar a região, as formas de gerir e se existe público. $\mathrm{O}$ negócio tende ao fracasso:

"Acho que é preciso um pouco de sensibilidade, precisa pensar mais com a razão. Enxergar se aquilo que você vai fazer vai ter público, não adianta nada se não tiver quem queira. Ver se não existe concorrência direta ali na região e se tiver ver se o mercado é grande o suficiente para você conseguir dividir com os outros". (...) "é fundamental ver o mercado e avaliar a sua estrutura. O que você tem de instrumentos para viabilizar o negócio".

A exploração é um fator importante para continuidade do negócio e para isso ele entende que o empreendedor precisa utilizar os meios mais utilizados na região, no caso da Rocinha, seriam carro de som, banners e a rádio. Independente do meio de exploração ele acredita que o mais eficiente na comunidade é o boca a boca, passa mais credibilidade e é de graça, mas esse meio é consequência do produto ou serviço, que precisa ser de qualidade para funcionar de uma forma mais natural.

A densidade populacional da Rocinha para Antônio é uma das vantagens em se empreender na Rocinha, os moradores em sua maioria consomem no mercado interno, 
impulsionando a economia local. E está planejando em expandir os seus negócios, mas em outro ramo, o de alimentos. Uma vez a população está expandindo, mais gente vai morar, do que sair da comunidade, para outro bairro ou favela, aumentando o mercado consumidor. Principalmente por estar numa localização geográfica nobre, com um custo mais baixo e tendo as facilidades em se locomover. Além desses fatores o entrevistado entende que isso o beneficia, uma vez que o mercado de moto é um dos mais utilizados:

"O mercado de moto é enorme e em constante crescimento. Mas de modo geral é porque a favela é gigante, senão me engano são quase 200mil moradores e a grande maioria faz tudo por lá, compra e come”. (...) "Primeiro o mercado interno que bomba. Quando pensamos em favela, logo imaginamos um pessoal mais humilde com poucos recursos, mas na Rocinha é diferente, existem muitos trabalhadores e tem uma boa fonte de renda. Então o mercado consumidor ali é gigantesco. E além das moto taxis, tem muita gente que tem moto, meu mercado é gigante lá".(..) "Tenho um plano de abrir outro negócio dentro da Rocinha, é uma semente e deve ser no ramo de alimentos, apesar de existir muita coisa lá dentro, acredito que ainda tem oportunidade pra isso".

Entretanto Antônio percebe que estar estabelecido na comunidade proporciona algumas vantagens, mas também há suas desvantagens, principalmente pelo fato que independente da qualidade do serviço que ele preste, dificilmente pessoas que não moram na Rocinha, irão para lá e caso tivesse uma oficina em outros bairros, o público seria mais diversificado:

"Eu fico com um publico restrito ao interno, poderia atender outros clientes, caso eu tivesse no asfalto. Porque quem mora no asfalto não vai levar a moto para consertar na Rocinha, até pode acontecer, mas é muito raro. Outro ponto é que nossa mecânica fica perto da Rua 1, então quando tem guerra entre bandido e policia nós precisamos fechar, porque ali as coisas ficam um pouco precipitadas, bem perigoso".

Apesar dessa desvantagem, ele compreende que existem diferenças entre empreender fora da favela, sobretudo nos processos burocráticos e na demora para 
consegui-los de acordo com as normas legais, e dentro da comunidade, onde as pessoas que criam um negócio, nem pensam nisso:

"Primeiro nas questões de legalização, na Rocinha nós não trabalhávamos com alvará, agora nós temos, graças ao incentivo do governo. Então passamos muito tempo sem pagar qualquer imposto. $E$ a pessoa que empreende no asfalto ele precisa disso tudo antes mesmo de abrir a empresa e isso custa caro. Além do tempo que demora, pra ficar certo, existe muita burocracia. Coisa que na favela, nem com obra nos preocupamos, a gente não precisa de projeto, arquiteto essas coisa, nós fazemos como a gente quer, como a gente acha que é o certo" (...) "até porque não existe fiscalização".

Em relação à UPP, ele crê que teve uma melhora, mas por estar no início e ainda existirem meliantes na comunidade, ora ou outra acontece algum conflito. Portanto, a interferência positiva em seu negócio foi pequena. O poder público nos anos 2000 ajudou na regularização das empresas da Rocinha, mas ele acredita que o governo poderia fazer mais, principalmente para incentivar a criação de novos negócios e também para legalização dos já existentes, entretanto em sua opinião, o governo faz ao contrário, tributa as empresas, sem ao menos dar algo em troca:

"No geral não. Acho que nem lá na favela e no asfalto, porque primeiro que é muito caro ter um negócio hoje em dia, você é tributado de todas as formas, segundo que não existe nenhum incentivo para legalizar os negócios. E isso afugenta muita gente que quer empreender".

\subsection{Aproximações e Afastamentos nos Discursos Analisados}

Analisando o discurso de cada entrevistado, foi possível perceber algumas aproximações e alguns afastamentos.

Em todos os discursos, quando o tema eram as características principais do empreendedor, foi comum aos entrevistados definirem o empreendedor como uma pessoa corajosa, persistente, com ousadia para arriscar em novos negócios e trabalhadora. 
Em relação às motivações, as falas foram diversas, como trabalhar com o que gosta, não ter chefe, independência, buscar o sucesso do modo que lhe for conveniente. Entretanto ficou claro que a maior motivação de todos os entrevistados é a remuneração (o que tornaria possível, por exemplo, uma qualidade de vida melhor).

Em relação à descoberta, avaliação e exploração de oportunidades, a percepção do contexto é utilizada pelos empreendedores, uma vez que quatro dos cinco entrevistados responderam que a forma de descobrir uma oportunidade é pelo convívio na comunidade, a relação com os moradores. A única que tem outra opinião foi Mariana, pois, para ela, a descoberta de uma oportunidade de negócio pode surgir a partir de uma necessidade do próprio empreendedor. A avaliação de um novo negócio teve, em suma, a mesma argumentação, na qual buscam informações sobre o mercado, a região que investirão e hábitos dos moradores. Sobre a exploração do potencial de um novo empreendimento, utilizam o boca a boca, já que todos se conhecem na comunidade e é um método sem custos, que passa credibilidade. Entretanto, houve algumas respostas diferentes, como a necessidade de renovar o que é vendido, se adaptar ao desejo do mercado. Outro entrevistado entende que a melhor forma de explorar é o empreendedor estar na hora e lugar, onde os consumidores terão necessidade de algum serviço, portanto a necessidade e a localização estão atreladas, para explorar o potencial do negócio.

No que diz respeito a empreender dentro e fora da favela, os entrevistados entendem que as principais diferenças, são os processos burocráticos, os impostos que, na favela, não são impeditivos para criar um negócio, enquanto, fora dela, esses procedimentos são vitais para abertura e continuidade de qualquer negócio. $E$ essas etapas são caras, o que também é um fator determinante, na opinião deles, empreender fora da favela é muito mais caro. A única resposta diferente das demais foi a de Vitor, que acredita que a principal diferença entre empreender nesses dois locais, é cultural

Quando o tema é a expansão dos negócios, o discurso dos empreendedores aproxima-se bastante, pois todos os entrevistados têm a pretensão de expandir o seu negócio ou até já expandiram. Entretanto isso é feito com cautela e para outros ramos, os entrevistados estão planejando em trabalhar no ramo de hospedagem, alimentação e locação de casas para moradia. Os únicos que avaliam a ampliação do ramo de 
atuação são; Mariana que pretende fazer uma loja de roupas femininas para festas e Vitor, que pretende expandir o seu trabalho para toda a Rocinha e para isso tem feito diversas parcerias.

Em relação às políticas públicas, todos os entrevistados dizem que já existiram programas, mas é necessário ações do Estado mais efetivas e constantes. Mariana acredita que o governo poderia atuar para melhorar a infraestrutura, o que incentivaria a criação de novos negócios. Quando perguntados os outros entrevistados associam a ação do governo a UPP. Neste sentido, a avaliação da UPP é delicada. Três empreendedores entendem que houve uma pequena melhora, um justifica que a ocupação é recente, enquanto que para os outros, o distanciamento dos moradores da cidade diminuiu, ou seja, essa política pública trouxe mais clientes. Entretanto os outros argumentam que teve um impacto negativo, uma vez que não conseguiram prender todos os traficantes, muitos ainda estão lá, resultando em alguns conflitos que ocorrem a qualquer momento. Os entrevistados também justificam que grande parte do dinheiro que circulava no mercado interno, era oriundo do tráfico, portanto o desenvolvimento local foi prejudicado.

\subsection{Vantagens e desvantagens percebidas}

As vantagens percebidas pelos empreendedores da Rocinha são; a alta densidade populacional, intensa movimentação de pessoas em qualquer período, a pluralidade desse mercado consumidor, que é crescente e fiel, e o fato de a maioria dos moradores da comunidade consumir nos negócios espalhados pela Rocinha, aquecendo e proporcionando a ampliação do comércio local. De forma adicional, a própria localização geográfica da comunidade apresenta-se como uma vantagem, por constituir uma região central do Rio de Janeiro. Está perto da Zona Sul, Oeste e Central, dos principais hotéis da cidade, e por isso acaba usufruindo de diversos modais de transporte para diversas regiões, o que facilita o negócio de cada empreendedor, seja direta ou indiretamente. Um exemplo são as pessoas que se mudam para Rocinha, por estar numa localização nobre com um ótimo custo benefício, resultando num crescimento do mercado consumidor interno. 
As desvantagens percebidas pelos empreendedores foram distintas, cada um entende as desvantagens de empreender na Rocinha de uma forma, o único que acredita que empreender na Rocinha não existe desvantagem, foi Leandro, moto taxista. Pedro entende que o acesso ao crédito acima do disponível pelo governo é difícil, quando tenta num outro banco, tem problema por não ter condições de fazer uma organização financeira e outro fator é a impossibilidade de expansão do negócio. Já Antônio e Vitor têm opiniões semelhantes, uma vez que os consumidores ficam restritos aos moradores da favela e turistas, pois ainda existe preconceito e desinteresse dos moradores de outros bairros do Rio de Janeiro em conhecer a Rocinha. O entendimento da Mariana é relacionado mais as ações públicas, que não fornecem uma infraestrutura, nem saneamento básico adequado e falta de acessibilidade em alguns pontos da comunidade, dificultando o empreendedor. 


\section{Conclusão e recomendações para novos estudos}

Nos últimos anos a favela de modo geral, por diversos fatores, tem sido vista de maneira diferente da anterior. O que antes era um local degradado, atualmente tem se tornado mais comercial, comprovada o aumento do poder de consumo das classes mais baixas.

O Rio de Janeiro teve um aumento considerável nos preços dos imóveis, tanto para compra, como para locação. Isso dificulta empreendedores na criação de seus negócios; o investimento inicial e custo para manter o negócio são muito altos. Somando a esses fatores, o mercado da cidade, assim como do Brasil, está em recessão. Portanto empreendedores estão precisando desistir de seus negócios e procurar praças que sejam mais baratas.

Percebendo o cenário atual do mercado, esse trabalho pretendeu analisar as vantagens e desvantagens competitivas em se empreender na comunidade da Rocinha, e assim ajudar empreendedores que queiram criar ou expandir seus negócios lá.

Para aprofundar a análise pretendida, investigou-se o empreendedorismo na ótica de Venkataraman (2010 apud ECKHARDT \& SHANE, 2003) e sobre o empreendedorismo e comportamento dos consumidores na favela de Meirelles \& Athayde (2014). Em seguida, ECKHARDT \& SHANE (2003) explicam as oportunidades de novos negócios e FREIRE-MEDEIROS (2009) sobre o ambiente e cultura na favela.

A metodologia de pesquisa do presente trabalho foi dividida em algumas etapas. Foi realizada uma pesquisa bibliográfica, através da análise de livros, sites, artigos e estudos científicos. Ao mesmo tempo foram realizadas cinco entrevistas em profundidade, com empreendedores da Rocinha de diferentes ramos, para poder identificar as vantagens e desvantagens de se empreender na favela da Rocinha a partir da percepção deles. 
A finalização dessa pesquisa foi uma análise cruzada dos discursos dos cinco empreendedores, tendo como base as seguintes categorias: características do empreendedor, perfil do empreendedor, empreendedorismo, motivações, descoberta, avaliação e exploração de um novo negócio, vantagem e desvantagem de se empreender na Rocinha, localização geográfica, diferença entre empreender na favela e fora, políticas públicas, UPP e expansão do negócio.

O resultado mostra que a Rocinha tem um mercado crescente e pulsante por vários motivos. Entre eles, o fato de grande parte dos moradores consumirem internamente. O investimento inicial é outra vantagem, pois é bem abaixo ao praticado nos bairros adjacentes. Por entre outros motivos, não precisar pagar alguns impostos e não despender dinheiro e tempo, quanto aos trâmites burocráticos, uma vez que não há fiscalização.

A localização é uma vantagem competitiva por ser bastante visitada e pela localização geográfica, a Rocinha, está sempre em o foco. Apesar dos entrevistados acharem que existe a necessidade de uma atuação mais eficaz e constante do governo. E a maioria ainda ter certo receio, principalmente com a UPP.

Apesar de o mercado em geral, ter sido mais favorável ao empreendedorismo há alguns anos, ainda existem boas oportunidades na Rocinha. O empreendedor é visto como uma pessoa admirável, pelos moradores que têm uma visão positiva, pois entendem que o sucesso dele, desenvolverá a comunidade como um todo, a oferta de produtos e a competitividade aumentarão.

Esse entendimento é muito importante para o empreendedor: os mesmos que o vêem como uma pessoa boa são seus potenciais/principais consumidores. Entretanto o empreendedor, principalmente o externo, precisa planejar em qual ponto ele terá o negócio, e deverá oferecer uma qualidade de serviço/produto igual ou melhor que serviria caso tivesse escolhido empreender em outras praças, pois os moradores da comunidade estão mais exigentes. Sendo bem tratados eles o ajudam a divulgar o negócio, através do boca a boca, uma das ferramentas de divulgação de maior credibilidade e mais utilizadas na Rocinha.

Quanto às desvantagens ao empreender na Rocinha, no entendimento dos empreendedores locais, foram identificados três principais fatores; 1) Falta 
infraestrutura e saneamento básico em alguns pontos; 2) Conflito entre tráfico e polícia; 3) Consumidores são restritos a moradores e turistas.

Portanto, o primeiro e segundo fatores são de responsabilidade do poder público, que deveria investir mais em saneamento básico e infraestrutura, além de agir para impedir a expansão desordenada da comunidade. Do jeito que está é inútil qualquer atuação, mas por outro lado a comunidade precisa ajudar o Estado nisso.

O segundo fator tem diminuído no decorrer do tempo, mas sem um programa de incentivo ao empreendedorismo, ao desenvolvimento da favela, o distanciamento cultural se perpetuará. Não adianta fazer UPP com formas de gerir e regras padrão. A Rocinha, assim como qualquer outra comunidade, tem suas próprias culturas e hábitos. Portanto, esse e qualquer programa do Estado precisam ser adaptados ao lugar, para que os moradores confiem e tendo como conseqüência uma diminuição da influência do tráfico. Como resultado dessas ações o terceiro fator perderia força, o preconceito e a sensação de insegurança, que é um dos principais impeditivos dos moradores, de outros bairros da cidade, de conhecerem a Rocinha. Embora já exista uma melhora, ela é insignificante comparada ao todo.

Deste modo, no ponto de vista dos empreendedores, iniciar um negócio na comunidade é uma boa oportunidade, por perceberem mais vantagens do que desvantagens. Caso haja ações mais incisivas de ambas as partes interessadas, governo e moradores; tendo como meta o desenvolvimento da Rocinha, o mercado interno deixará de ser visto, como uma potência no médio/longo prazo, para uma realidade no curto.

\subsection{Sugestões e recomendações para novas pesquisas}

Como desdobramentos futuros, essa linha de pesquisa pode ser estendida através de uma análise mais ampla, buscando uma maior heterogeneidade quanto à idade e ao ramo de negócio dos entrevistados.

Outra sugestão seria entender o motivo pelos quais os turistas vão visitar ou se hospedam na comunidade. Buscar no discurso deles, atitudes que podem ser desenvolvidas para ter uma atração maior de pessoas de fora da Rocinha. E ampliar essa pesquisa para os moradores dos bairros adjacentes, a fim de descobrir quais os 
reais motivos para ainda existir esse distanciamento cultural e o que pode ser feito para mudar.

Por fim, entrevistar os moradores da Rocinha, para saber a opinião deles sobre o mercado interno, suas necessidades e a forma com que eles querem que essas necessidades sejam atendidas. Buscando em conjunto com os empreendedores, alternativas focadas no tratamento e vendas, podendo surgir novas oportunidades dentro da comunidade. 
6. Referências Bibliográficas

ACKOFF, R. L. Planejamento Empresarial. Rio de Janeiro: LTC, 1978.

ALVAREZ, S. A., \& BARNEY, J. B. Entrepreneurship and Epistemology: The Philosophical Underpinnings of the Study of Entrepreneurial Opportunities. The Academy of Management Annals , 557-583, 2010.

BETHLEM, A. Gestão estratégica de empresas brasileiras. São Paulo: Atlas, 2005.

CARDOSO, C. Não é hora de comprar imóveis no Rio, dizem economistas. Disponível em <http://g1.globo.com/rio-dejaneiro/noticia/2014/03/nao-e-hora-de-comprar-imoveis-no-rio-dizemeconomistas.html>. Acesso em 23 mar. 2014

ChIAVEnAtO, I. Administração nos Novos Tempos. $4^{\text {a }}$ ed. Rio de Janeiro, Elsevier, 2004.

CHIAVENATO, I. Empreendedorismo - Dando asas ao espírito empreendedor. São Paulo, Saraiva, 2005.

CONGLOMERADO. Oportunidade de Negócio. Disponível em $<$ http://conglomerado.com.br/oportunidade-de-negocio/>. Acesso em 30 mar. 2015

CostA, A. d., \& SARAIVA, L. A. O Consenso, o Exemplo e a Inexorabilidade: Discursos Hegêmonicos acerca do 
Empreendedorimo como Mecanismo de Reprodução do Capital. Encontro da ANPAD 2011, (pp. 1-17). Rio de Janeiro, 2011.

DE hOLANDA FERREIRA, A. B. Novo Dicionário da Língua Portuguesa. Rio de Janeiro: Nova Fronteira, 1975.

DE MELLO, C. M., Neves, H. L., Valenzuela, J. B., Mattiello, K., \& Machado, H. V. Do Que Estamos Falando Quando Falamos Empreendedorismo no Brasil? Revista de Administração da UNIMEP , 80-98, Jan./Abr. 2010.

DE MELLO, J. O. "Urbanização Sim, Remoção Não" - A atuação da federação das associaçoes de favelas do estado da Guanabara nas decadas de 1960 e 1970. Niteroi, 2014.

ECKHARDT, J. T., \& SHANE, S. A. Opportunities and Entrepreneurship. Journal of Management , 333-349, 2003.

ENDEAVOR. (2014). Cultura Empreendedora no Brasil. Disponível em $<$ http://info.endeavor.org.br/hs-fs/hub/257101/file-2053612775-pdf/ENDEAVORPESQ PERFIS-RELAT\%C3\%93RIO FINAL.pdf?submissionGuid=cafd88297f89-4ddf-802a-74517dac866b>. Acesso em 17 Nov. 2014.

FREIRE-MEDEIROS, B. Gringo na laje. Rio de Janeiro: FGV, 2009.

GALDO, R. Rio é a cidade com maior população em favelas do Brasil. Disponivel em <http://oglobo.globo.com/brasil/rio-a-cidade-com-maiorpopulacao-em-favelas-do-brasil-3489272>. Acesso em 22 Set. 2014.

GEM. GEM - Empreendedorismo na região sudeste do Brasil. Paraná: SEBRAE/IBQP/UFPR, 2013.

GLOBO.COM. Quatro milhões de empresas são legalizadas em cinco anos no Brasil. Disponível em <http://g1.globo.com/bom-diabrasil/noticia/2014/07/quatro-milhoes-de-empresas-sao-legalizadas-em-cincoanos-no-brasil.html>. Acesso em 12 Out. 2014.

INVENTTA. A inovação: definição, conceitos e exemplos. Disponivel em <http://inventta.net/radar-inovacao/a-inovacao/>. Aceso em 1 Nov. 2014. 
LOPES, R. d. Dinâmicas Comerciais no Espaço Intra-Urbano Favelado: $\mathrm{O}$ caso da Rocinha. Tamoios , 75-85, 2009.

LOPES, R. M. Educação empreendedora - conceitos, modelos e práticas. Rio de Janeiro: Elsevier, 2010.

MÁRCIO, C. Estratégia: corporativa, de negócios e funcional. Disponível em $<$ http://www.administradores.com.br/artigos/academico/estrategia-corporativade-negocios-e-funcional/70405/>. Acesso em 7 Nov. 2014.

MARIANO, S. R., Moraes, J., \& Medeiros, S. J. Empreendedorismo na Base da Pirâmide Social: o Fenômeno das Lan Houses na Comunidade da Rocinha no Rio de Janeiro. Encontro da ANPAD 2011, (pp. 1-17). Rio de Janeiro, 2011.

MEDEIROS, L. Comércio em favelas se reinventa após UPPS. Disponível em $<$ http://www.brasil247.com/pt/247/favela247/131381/Com\%C3\%A9rcio-emfavelas-se-reinventa-ap\%C3\%B3s-UPPs.htm>. Acesso em 10 Set. 2014.

MEIRELLES, R., \& ATHAYDE, C. Um país chamado favela. São Paulo: Gente, 2014.

MENDONÇA, A. V. Rio recebeu $\mathbf{8 8 6}$ mil turistas durante a Copa do Mundo, diz Riotur. Disponível em http://g1.globo.com/rio-dejaneiro/noticia/2014/07/rio-recebeu-886-mil-turistas-durante-copa-do-mundo-dizriotur.html>. Acesso em 30 Ago. 2014.

MENEZES, R. Uma metodologia para boas práticas de formação empreendedora. Curitiba: Cobenge, 2007.

MINISTERIO DO DESENVOLVIMENTO SOCIAL E COMBATE A FOME. Bolsa Familia. Disponivel em <http://mds.gov.br/bolsafamilia>. Acesso em 3 Mar. 2015.

MINISTÉRIO DO TURISMO. Anuário Estatístico de Turismo - 2014 Ano Base 2013. Disponivel em $<w w w$.dadosefatos.turismo.gov.br/dadosefatos/anuario/index.html>. Acesso em 7 Set. 2014. 
OLIVEIRA, D. P. Planejamento estratégico: conceitos, metodologia e práticas $22^{\mathrm{a}}$ ed. São Paulo: Atlas, 2005.

OSBORN, C. A História das Urbanizações nas Favelas Parte II: Favela-Bairro (1988-2008).

Disponível

em

<http://rioonwatch.org.br/?p=5042>. Acesso em 18 Mar. 2015.

POPULAR, D. Geração C - Especial: Comunidades cariocas. Rio de Janeiro: Data Popular/CUFA, 2013.

RAMOS, P. $\mathbf{O}$ que é criatividade? Disponível em $<$ http://www.administradores.com.br/artigos/cotidiano/o-que-ecriatividade/59339/>. Acesso em 14 Nov. 2014.

RENI. O ciclo de vida de uma organização: fatores preponderantes para 0 fim antes do tempo. Disponível em $<$ http://www.administradores.com.br/artigos/economia-e-financas/o-ciclo-devida-de-uma-organizacao-fatores-preponderantes-para-o-fim-antes-dotempo/65018/>. Acesso em 5 Out. 2014.

SEBRAE. GEM 2013: recorde de empreendedores por oportunidade. Disponivel em $<$ http://www.sebrae.com.br/sites/PortalSebrae/estudos pesquisas/GEM-2013:recorde-de-empreendedores-por-oportunidade, detalhe,29>. Acesso em 17 Nov. 2014.

SECRETARIA DE ASSUNTOS ESTRATÉGICOS DO BRASIL. Número de beneficiados pelo Brasil sem Miséria deve subir em $600 \mathrm{mil} \mathrm{no}$ ano que vem. Disponível em <www.sae.gov.br/site/?p=18062>. Acesso em 3 Nov. 2014.

SECRETARIA DE SEGURANÇA DO ESTADO DO RIO DE JANEIRO. O que é? Disponível em <http://www.uppri.com/index.php/o que e upp >. Acesso em 16 Nov. 2014.

SOUL BRASILEIRO. Soul Brasileiro. Disponivel em $<$ http://soulbrasileiro.com.br/main/rio-de-janeiro/favelas/rocinha/rocinha/>. Acesso 27 Mar. 2015.

SUDDABY, R., BRUTON, G. B., \& STEVEN, X. S. Entrepreneurship through a qualitative lens: Insights on the construction and/or 
discovery of entrepreneurial opportunity. Journal of Business Venturing , 1-10, 2015.

VALLARDES, L. d. A invenção da favela. Rio de Janeiro: FGV, 2000.

VergarA, S. C. Projetos e Relatórios de Pesquisa em Administração. São Paulo: Atlas, 2014.

VIEIRA, L. Prahalad e a riqueza na base da pirâmide. Disponível em $<$ http://www.administradores.com.br/artigos/tecnologia/prahalad-e-a-riqueza-nabase-da-piramide/690/>. Acesso em 15 Nov. 2014. 


\section{Anexo 1}

\section{Roteiro Entrevista}

\section{Primeiro bloco: Empreendedor/Empreendedorismo}

- Para você o que é empreendedorismo?

- Na sua opinião, qualquer um pode empreender?

- Você se considera um empreendedor? Por quê?

- Quais as principais características que você acha que o empreendedor deve ter?

- Por que você empreende? Quais são as suas motivações para empreender?

- Você poderia me falar um pouco sobre a história dos seus negócios?

- Como surge a ideia de um novo negócio? (Descoberta) Você poderia me dar um exemplo?

- Antes de criar os seus negócios, você se espelha (ou se espelhou) em alguém ou em algum outro empreendimento? 
- Como você avalia o potencial dessa ideia de um novo negócio? (Avaliação) Você poderia me dar um exemplo?

- Como você explora e/ou põe em prática essa ideia de um novo negócio? (Exploração) Você poderia me dar um exemplo?

- É fácil empreender? E empreender no Brasil? E no Rio de Janeiro?

- Qual foi o seu maior sucesso nos negócios? Por quê?

- E qual foi o seu maior fracasso nos negócios? Por quê?

- Essa empresa é seu primeiro empreendimento?

- Há quanto tempo você tem essa empresa? Ela já gera lucro?

- Quanto tempo depois da criação, você conseguiu retirar algum dinheiro (salário)?

- Como você se vê:

( ) Empreendedor de origem mais humilde que desde criança pratica atitudes empreendedoras. Você busca realizar seus sonhos e procura uma maneira para atingir essa meta. (Nato)

( ) Empreendedor que acredita na própria forma de condução dos negócios, independente do que os outros dizem e tem dificuldade de trabalhar em algo que não acredite. (Meu jeito)

( ) Empreendedor insatisfeito com o mercado de trabalho que agarra uma oportunidade à sua frente. (Situacionista)

( ) Empreendedor que ao longo de sua vida foi habituado no meio de empreendedores, portanto tem experiência no meio do empreendedorismo e assim resolve ter seu próprio negócio ou administra os negócios da família. (Herdeiro) 
( ) Empreendedor que tem nos seus valores e idéias a base para empreender, tem como objetivo principal a melhoria da comunidade e impactar efetivamente a sociedade. O lucro é bom, mas não primordial. (Idealista)

( ) Empreendedor que visa o lucro primordialmente, pois empreende para alcançar fortuna. Já estavam com uma boa posição no mercado de trabalho, mas como são ambiciosos, preferiram empreender para ganhar mais dinheiro num espaço menor de tempo.(Busca do milhão)

\section{Segundo bloco: Oportunidades/Percepcão do contexto}

- Em sua opinião, existem diferenças entre empreender em favela e/ou no asfalto? Ou seja, existem diferenças em se ter um negócio na favela e/ou no asfalto?

- Por que você escolheu empreender na Rocinha? Ou seja, o que te levou a criar e estabelecer os seus negócios na favela da Rocinha?

- Quais seriam as vantagens de se empreender na Rocinha?

- E quais seriam as desvantagens? Existem desvantagens? Você poderia me dar um exemplo?

- Quais seriam as principais oportunidades de negócio em empreender na favela da Rocinha?

- O fato da Rocinha ser conhecida internacionalmente é uma oportunidade de negócio?

- E a localização geográfica da Rocinha (perto da zona sul e dos hotéis)? Também é uma oportunidade de negócio? 
- Existem benefícios ou incentivos do governo para empreender na favela?

- Você já se beneficiou de algum deles? Você conhece alguém que já se beneficiou?

- Você pretende expandir o seu negócio? E para isso, o que precisa?

- Você acha que o governo (e suas políticas públicas) ajudam na criação e/ou expansão dos negócios? O governo te ajudou? Você poderia me dar um exemplo?

- Na sua opinião, a criação das UPP's contribuiu para os seus negócios? Por quê?

- Quem são os seus consumidores/clientes? Os seus clientes são da comunidade ou de fora dela?

- Os consumidores/clientes da favela da Rocinha podem ser considerados como uma oportunidade de negócio? O que você faz para atrair mais clientes?

- Por algum fator (interno ou externo)/mudança (local, concorrência, violência) você já teve que mudar a forma de gerir ou até mesmo o seu negócio? 